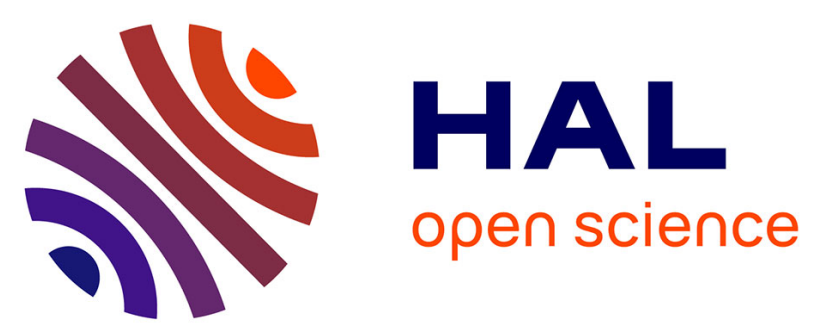

\title{
Aerosol direct radiative forcing over Djougou (northern Benin) during the African Monsoon Multidisciplinary Analysis dry season experiment (Special Observation Period-0)
}

Michel Mallet, Véronique Pont, Catherine Liousse, L. Gomes, Jacques Pelon, S. Osborne, J. Haywood, Jean-Claude Roger, Philippe Dubuisson, Armand Mariscal, et al.

\section{- To cite this version:}

Michel Mallet, Véronique Pont, Catherine Liousse, L. Gomes, Jacques Pelon, et al.. Aerosol direct radiative forcing over Djougou (northern Benin) during the African Monsoon Multidisciplinary Analysis dry season experiment (Special Observation Period-0). Journal of Geophysical Research: Atmospheres, 2008, 113 (D23), pp.D00C01. 10.1029/2007JD009419 . hal-00296608

\section{HAL Id: hal-00296608 https://hal.science/hal-00296608}

Submitted on 4 Mar 2016

HAL is a multi-disciplinary open access archive for the deposit and dissemination of scientific research documents, whether they are published or not. The documents may come from teaching and research institutions in France or abroad, or from public or private research centers.
L'archive ouverte pluridisciplinaire HAL, est destinée au dépôt et à la diffusion de documents scientifiques de niveau recherche, publiés ou non, émanant des établissements d'enseignement et de recherche français ou étrangers, des laboratoires publics ou privés. 


\title{
Aerosol direct radiative forcing over Djougou (northern Benin) during the African Monsoon Multidisciplinary Analysis dry season experiment (Special Observation Period-0)
}

\author{
M. Mallet, ${ }^{1}$ V. Pont,${ }^{1}$ C. Liousse, ${ }^{1}$ L. Gomes, ${ }^{2}$ J. Pelon, ${ }^{3}$ S. Osborne, ${ }^{4}$ J. Haywood, ${ }^{4}$ \\ J. C. Roger, ${ }^{5}$ P. Dubuisson, ${ }^{6}$ A. Mariscal, ${ }^{1}$ V. Thouret, ${ }^{1}$ and P. Goloub ${ }^{7}$ \\ Received 26 September 2007; revised 18 March 2008; accepted 24 March 2008; published 8 July 2008.
}

[1] The purpose of this work is to investigate the direct radiative forcing of aerosols over the supersite of Djougou (northern Benin) during the African Monsoon Multidisciplinary Analyses dry season experiment. We focus our simulations on the top of atmosphere, bottom of atmosphere, and atmosphere radiative forcings. During the dry season period, Sun photometer measurements indicate a rather turbid atmosphere with a mean aerosol optical depth for the overall period of $0.78 \pm 0.24$ (at $440 \mathrm{~nm}$ ). The aerosol absorption coefficient estimated at the surface ranged between 2.3 and $37.3 \mathrm{Mm}^{-1}$ (mean value $15.2 \pm 10.6 \mathrm{Mm}^{-1}$ at $520 \mathrm{~nm}$ ) and the scattering coefficient between 44.5 and $232.3 \mathrm{Mm}^{-1}$ (mean $145 \pm 59 \mathrm{Mm}^{-1}$ at $520 \mathrm{~nm}$ ). This leads to a single scattering albedo of between 0.81 and 0.98 (at $520 \mathrm{~nm}$ ) with a mean (and standard deviation) value of $0.91 \pm 0.05$, indicating moderately absorbing aerosols. In parallel, micropulse lidar measurements indicate the presence of two distinct aerosol layers, with a first one located between the surface and $1 \mathrm{~km}$ and a second one located above $1.5-4.0 \mathrm{~km}$. On the basis of surface and aircraft observations, sunphotometer measurements, lidar profiles, and Moderate Resolution Imagaing Spectroradiometer sensor an estimation of the daily clear sky direct radiative forcing has been estimated for the 17-24 January 2006 period. Simulations indicate that aerosols reduce significantly the solar energy reaching the surface (mean $\Delta F_{\mathrm{BOA}}=-61.5 \mathrm{~W} / \mathrm{m}^{2}$ ) by reflection to space (mean $\Delta F_{\mathrm{TOA}}=-18.4 \mathrm{~W} / \mathrm{m}^{2}$ ) but predominantly by absorption of the solar radiation into the atmosphere (mean $\Delta F_{\mathrm{ATM}}=+43.1 \mathrm{~W} / \mathrm{m}^{2}$ ). The mean heating rate at the surface and within the elevated biomass burning layer is considerably enhanced by 1.50 and $1.90 \mathrm{~K} \mathrm{day}^{-1}$, respectively.

Citation: Mallet, M., et al. (2008), Aerosol direct radiative forcing over Djougou (northern Benin) during the African Monsoon Multidisciplinary Analysis dry season experiment (Special Observation Period-0), J. Geophys. Res., 113, D00C01, doi:10.1029/2007JD009419.

\section{Introduction}

[2] Although atmospheric aerosols are recognized to be a crucial agent of climate change [ntergovernmental Panel on Climate Change (IPCC), 2007], the estimation of their impact on climate remains an important scientific challenge. Indeed, in contrast with the radiative forcing attributed to greenhouse gases, which may be determined to a reasonably high degree of accuracy, the uncertainties related to aerosol radiative forcings remain very large [IPCC, 2007]. This is in the first place because of the complexity of aerosols.

\footnotetext{
${ }^{1}$ Laboratoire d'Aérologie, UPS, UMR5560, CNRS, Toulouse, France. ${ }^{2}$ CNRM, Météo-France, Toulouse, France.

${ }^{3}$ Service d'Aéronomie, University of Jussieu, Paris, France.

${ }^{4}$ Met Office, Exeter, UK.

${ }^{5}$ LAMP, OPGC, Clermont-Ferrand, France.

${ }^{6}$ LOCL/MREN, ELICO, Wimereux, France.

${ }^{7}$ Laboratoire of Optique Atmospherique, USTL, CNRS, Lille, France.
}

Copyright 2008 by the American Geophysical Union. 0148-0227/08/2007JD009419
Atmospheric particles have different sources, sizes, chemical compositions, mixing, shapes, optical properties and lifetimes, which makes it difficult to get an accurate estimation of their climatic impact at regional or global scale.

[3] Among all sources of atmospheric particles around the world, Western Africa is the world's largest source of biomass burning aerosols and mineral dust. Satellite observations indicate that these aerosol plumes, characterized by high aerosol optical depths (often greater than one in the visible range) are the most widespread, persistent and dense observed at global scale. The effect of such plumes of dust and smoke aerosols on climate change represents one of the largest uncertainties in the Earth radiative budget.

[4] Atmospheric aerosols emitted in Western Africa can modify the radiative budget directly by absorption or scattering of solar radiations. Additionally, they can modify cloud microphysics and cloud lifetime when particles act as cloud condensation nuclei [Twomey, 1977]. Furthermore, as dust and smoke particles are able to absorb solar radiation, the radiative heating due to aerosol layers can modify 


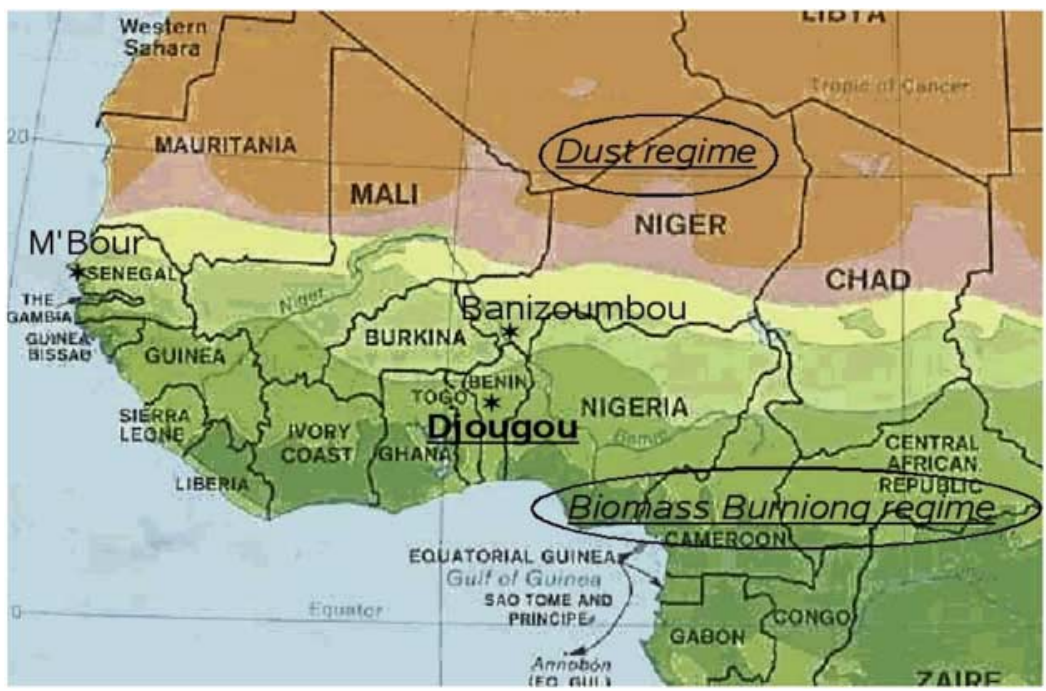

Figure 1. Location of the Djougou ground-based station (northern Benin).

atmospheric dynamics and suppress convection, resulting in evaporation of clouds [Ackerman et al., 2000]. This effect, called the "semidirect" effect, can lead to a positive forcing by reducing cloud fractional cover and counterbalancing the aerosol indirect effect. As examples, Koren et al. [2004] have demonstrated the reduction in cumulus cloud cover over the Amazon region during the smoke season, whereas Abel et al. [2005] indicate significant regional direct effect of smoke particles over the Southern African region during anthropogenic burning activities.

[5] Hence, dust and smoke particles coming from the West Africa region could strongly modify the regional or global climate as they have the potential to be exported over great distances by prevailing winds and atmospheric waves. Improved representation of their climatic effects requires, in addition to modeling exercises and satellite observations, ground-based and integrated column measurements of their physical, chemical and optical properties, associated with their vertical distribution. This specific question represents one of the objectives of the African Monsoon Multidisciplinary Analysis (AMMA) project [Redelsperger et al., 2006], as few data characterizing optical properties and direct radiative forcing of aerosols in the Western Africa region are available in the literature.

[6] In this work, we present results of aerosol optical properties and direct radiative impact obtained during January 2006, in the frame of the Special Observation Period-0 (SOP-0) experiment (J. M. Haywood et al., Overview of the dust and biomass-burning experiment and AMMA SOP-0, submitted to Journal of Geophysical Research, 2008), on the Djougou ground-based station $\left(9.70^{\circ} \mathrm{N} / 1.68^{\circ} \mathrm{W}\right.$, northern Benin), which was administered by the Laboratoire d'Aérologie (France, Toulouse). Among all sites instrumented during AMMA, the measurements performed at Djougou represent a unique database for studying the microphysical and optical properties of expected mixed aerosols (dust and biomass burning), compared to other sites located in the Sahelian dust region, north of the main biomass burning areas (Figure 1). We focus our analysis during the dry season, as maximum emissions of biomass burning aerosols occur during the December to February period.

[7] The estimation of the aerosol radiative forcing have been performed using the discrete ordinate Radiative Transfer Model (RTM) GAME (Global Atmospheric Model) [Dubuisson et al., 1996, 2004]. Radiative transfer computations depend on several parameters such as the spectral values of solar radiation incident on the atmosphere, the spectral variation of the aerosol optical depth (AOD), single scattering albedo (SSA), asymmetry parameter $(g)$, surface albedo, and associated vertical profiles of atmospheric (temperature, relative humidity and ozone concentration) properties.

[8] The methodology used for computing the aerosol clear sky radiative impact is described in detail by Mallet et al. [2006] and Roger et al. [2006]. Briefly, this method relies on a synergetic approach using in situ optical measurements of the aerosol associated with integrated measurements (Sun photometer, lidar, airborne, and satellite measurements) and a radiative transfer code which calculates the aerosol direct radiative forcing.

[9] In this article, the methodology used to measure absorbing and scattering coefficients is presented in section 3 and the results obtained in terms of aerosol optical properties (AOD, SSA and asymmetry parameter) and direct clear sky radiative forcing are presented in section 4 .

\section{Experimental Procedures}

[10] During the AMMA dry season experiment, several sites (Figure 1), (Djougou (Benin), Niamey (Niger), Banizoumbou (Niger) and M'Bour (Senegal)) were equipped with in situ and remote sensing instruments for characterizing the microphysical and optical properties of dust and biomass burning aerosols, their mixing, vertical structure, transport and radiative forcings. These groundbased observations were completed by aircraft (Facility for Airborne Atmospheric Measurements BAe 146) and ultralight aircraft (LSCE/CNRS-CEA) measurements, as well as satellite (Moderate Resolution Imagaing Spectroradiometer (MODIS)) observations. 


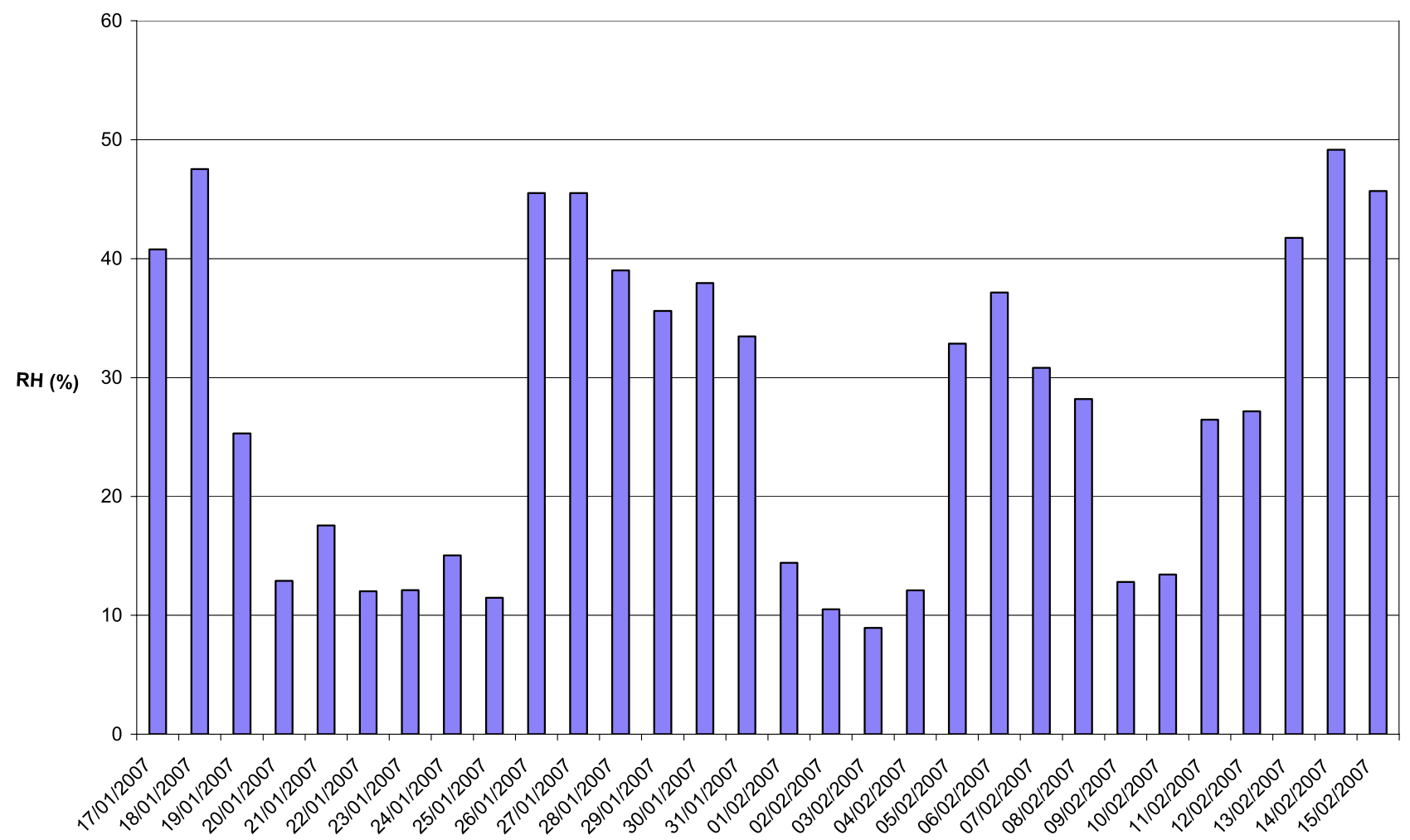

Figure 2. Averaged daytime (0800-1800 UTC) of relative humidity (RH) at Djougou during the 17 January to 15 February period.

[11] Aerosol ground-based instrumentation deployed at Djougou was dedicated to characterize the chemical composition of particles and their physical (number size distribution) and optical (absorption and scattering) properties, by using, respectively, a 13-stage Dekati impactor, a Differential Mobility Analyzer (DMA) $\left(D_{p}<0.5 \mu \mathrm{m}\right)$ connected to a Condensation Particle Counter (TSI model 3010), a GRIMM $\left(D_{p}>0.5 \mu \mathrm{m}\right)$ optical particle counter, a multichannel Aethalometer (model AE-10, MAGEE Scientific; Berkeley, USA) and a single channel Nephelometer (model ECOTECH M9003). A pyranometer (Kipp \& Zonen) has also been used to obtain the downward radiative fluxes across the shortwave wavelengths and near infrared region $(0.4-1.1 \mu \mathrm{m})$.

[12] Associated with our ground-based instrumentation, a sunphotometer of the PHOTONS network (French part of the Aerosol Robotic Network (AERONET)) was also used to estimate aerosol microphysical and optical properties for the whole atmospheric column [Dubovik et al., 2000, 2002; Dubovik and King, 2000]. Finally, over Djougou, the vertical profiles of the attenuated backscattering and extinction coefficients have been estimated from an aerosol micropulse lidar (MPL) (model CE 370-2), developed by CIMEL, which is a micropulse system operating at $532 \mathrm{~nm}$ [Pelon et al., 2008]. Measurements are taken according to a standard sequence of $10 \mathrm{~min}$ acquisition every $30 \mathrm{~min}$.

\section{Methodology for Estimating Absorbing and Scattering Coefficients}

\subsection{Aerosol Absorbing Coefficient}

[13] The aerosol absorption coefficient $\left(b_{\text {abs }}\right)$ was estimated by an AE10 aethalometer. It should be noted that, following the work of Schmid et al. [2006], who reported no statistically significant dependence of ambient absorbing coefficient on relative humidity $(\mathrm{RH})$ (for values comprised between 40 and $80 \%$ ), we do not take into account corrections of $b_{\text {abs }}$ with RH. First, the absorbing coefficient is defined with the Beer-Lambert's law

$$
I=I_{0} \exp \left(-b_{\mathrm{abs}} x\right)
$$

where $I_{0}$ is the intensity of the incoming light and $I$ the remaining light intensity after passing through a filter with the thickness $x$. The attenuation (ATN) is given as a percentage and is defined by the following relation

$$
\mathrm{ATN}=\ln \left(I_{0} / I\right) .
$$

The aethalometer attenuation coefficient $\left(b_{\mathrm{ATN}}\right)$ is defined as

$$
b_{\mathrm{ATN}}=(A / Q) \times(\Delta \mathrm{ATN} / \Delta t),
$$

where $A$ is the filter spot area, $Q$ the volumetric flow rate, and $\triangle \mathrm{ATN}$ is the change in attenuation during the interval $\Delta t$. It is well known that $b_{\mathrm{ATN}}$ may differ from the true aerosol absorption coefficient $b_{\mathrm{abs}}$. Hence, the parameters $C$ and $R(\mathrm{ATN})$ are introduced by Weingartner et al. [2003] in order to convert aethalometer attenuation measurements to "real" absorption coefficients. The following relationship is used:

$$
b_{\mathrm{abs}}=\frac{b_{\mathrm{ATN}}}{C \times R(\mathrm{ATN})},
$$



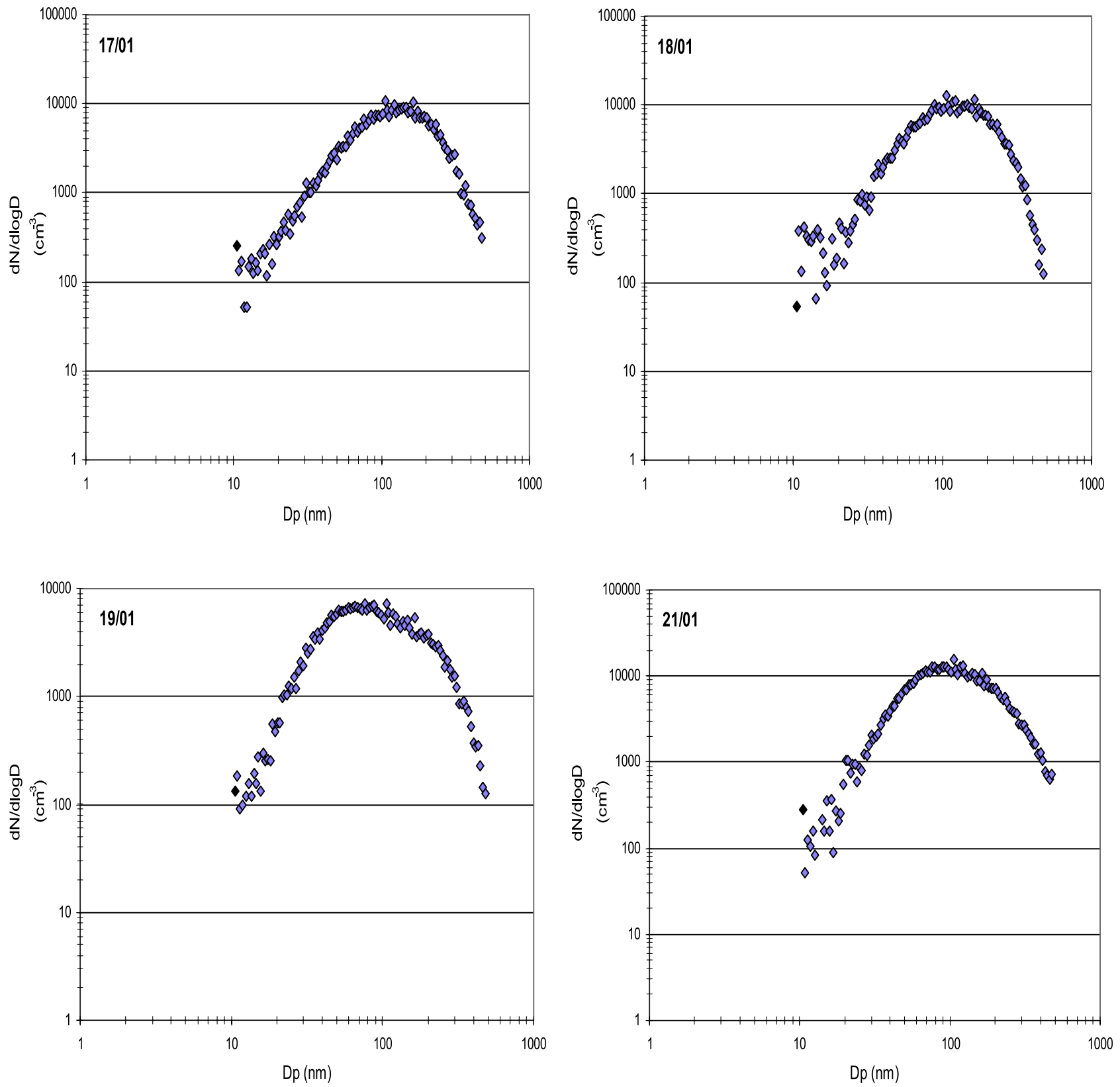

Figure 3. Aerosol number size distribution measured from Differential Mobility Analyzer (DMA) at Djougou for the $17,18,19$, and 21 January.

where $C$ and $R$ describe the two effects which modify the optical properties of filter particles. As mentioned by Weingartner et al. [2003], $C$ represents corrections due to the multiple scattering of the light beam between the filter fibers, leading to enhanced light absorption of the deposited particles [Liousse et al., 1993]. The constant $C$ mainly depends on the nature of the filter used. Petzold et al. [1997] reported values of $C$ between 1.9 and 2.5. In this work, we used a value of 2.14 (E. Weingartner, personal communication, 2006). However, sensitivity tests have been performed and show an accuracy of $\pm 12 \%$ on $b_{\text {abs}}$, following the value used for $C$.

[14] The second effect, the "shadowing effect," is linked to the amount of aerosol particles embedded in the filter and optical properties of the deposited particles. This effect is described through the empirical function of $R(\mathrm{ATN})$. For unloaded filters, $R$ is equal to $1(R(\mathrm{ATN}=0)=1)$. In case of high filter loadings, the absorbing particles in the filter are able to absorb a higher fraction of the scattered light, leading to a reduction of the optical path in the filter $(R \leq 1)$.

[15] Weingartner et al. [2003] reported that the shadowing effect of the particles is very pronounced for "pure" soot particles while it is almost negligible for aged atmospheric aerosols. This difference at the remote site is explained by the incorporation of a high amount of scattering aerosol material, which partially compensates the shadowing effect. Hence, in this work, considering that Djougou is not located at the sources of biomass burning emissions, 


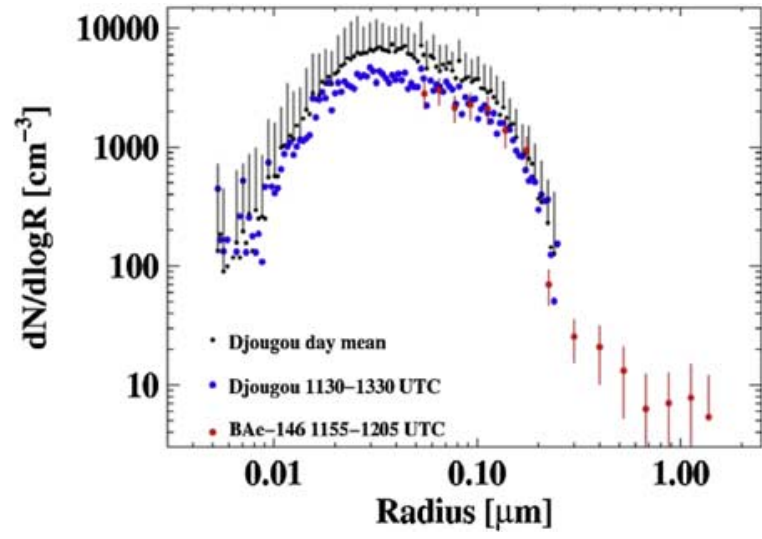

Figure 4. Comparisons between DMA number size distributions measured at Djougou and onboard the BAe 146 aircraft for the passage over Djougou (19 January). Vertical bars show \pm 1 standard deviation for the aircraft data and \pm 1 standard deviation for the Djougou day mean.

we used $R(\mathrm{ATN})=1$. The absorption coefficient is then computed as follow:

$$
b_{\mathrm{abs}}=\frac{b_{\mathrm{ATN}}}{2.14}
$$

\subsection{Aerosol Scattering Coefficient}

[16] The particle scattering coefficient $\left(b_{\text {neph }}\right)$ was measured at $520 \mathrm{~nm}$ by an ECOTECH nephelometer. Air is sampled through the semi-isokinetic inlet and the sample $\mathrm{RH}$ is maintained below $40 \%$. It should be noted here that corrections on the scattering coefficient due to RH have been taken into account only in case of ambient RH larger than $40 \%$ by using Magi and Hobbs's [2003] relations.
[17] The RH dependence on $b_{\text {scat }}$ is generally fitted with the following empirical function:

$$
b_{\text {scat }}=b_{\text {scat_dry }}\left[1+a(\mathrm{RH} / 100)^{b}\right],
$$

where $b_{\text {scat }}$ is the light scattering at ambient $\mathrm{RH}, b_{\text {scat dry }}$ is the light scattering coefficient in dry state, $a$ and $\bar{b}$ are empirical fitting parameters. At the surface, we have used the values of $2.55 \pm 0.19$ and $3.59 \pm 0.33$, for $a$ and $b$, respectively, corresponding to regional air samples obtained during SAFARI 2000 by Magi and Hobbs [2003]. It should be noted that this correction has been only used in few cases, as the ambient $\mathrm{RH}$ was generally lower than $45 \%$ (Figure 2) during the SOP-0.

[18] One of the major sources of errors from the nephelometer originates from the instrument geometrical limitations as the nephelometer cannot detect the entire phase function of the scattered light; it only measures aerosol light scattering coefficient for angular integration of $7^{\circ}-170^{\circ}$. Hence, the results provided by the nephelometer measurements underestimate the actual scattering coefficient. This effect has been shown to be low for submicron aerosols, whereas the errors can be higher [Alfaro et al., 2003] for supermicron particles. In order to take this effect into account, the following relation is used:

$$
b_{\text {scat }(520)}=b_{\text {neph }(520)} C_{\text {corr }} \text {, }
$$

where $b_{\text {neph(520) }}$ is the dry scattering coefficient directly measured from the nephelometer at $520 \mathrm{~nm}, C_{\text {corr }}$ is the correction factor and $b_{\text {scat }(520)}$ is the real dry scattering coefficient.

[19] For anthropogenic aerosols, Carrico et al. [2000] reported a slight underestimation of the total scattering coefficient of about 4\% and Formenti et al. [2002] reported

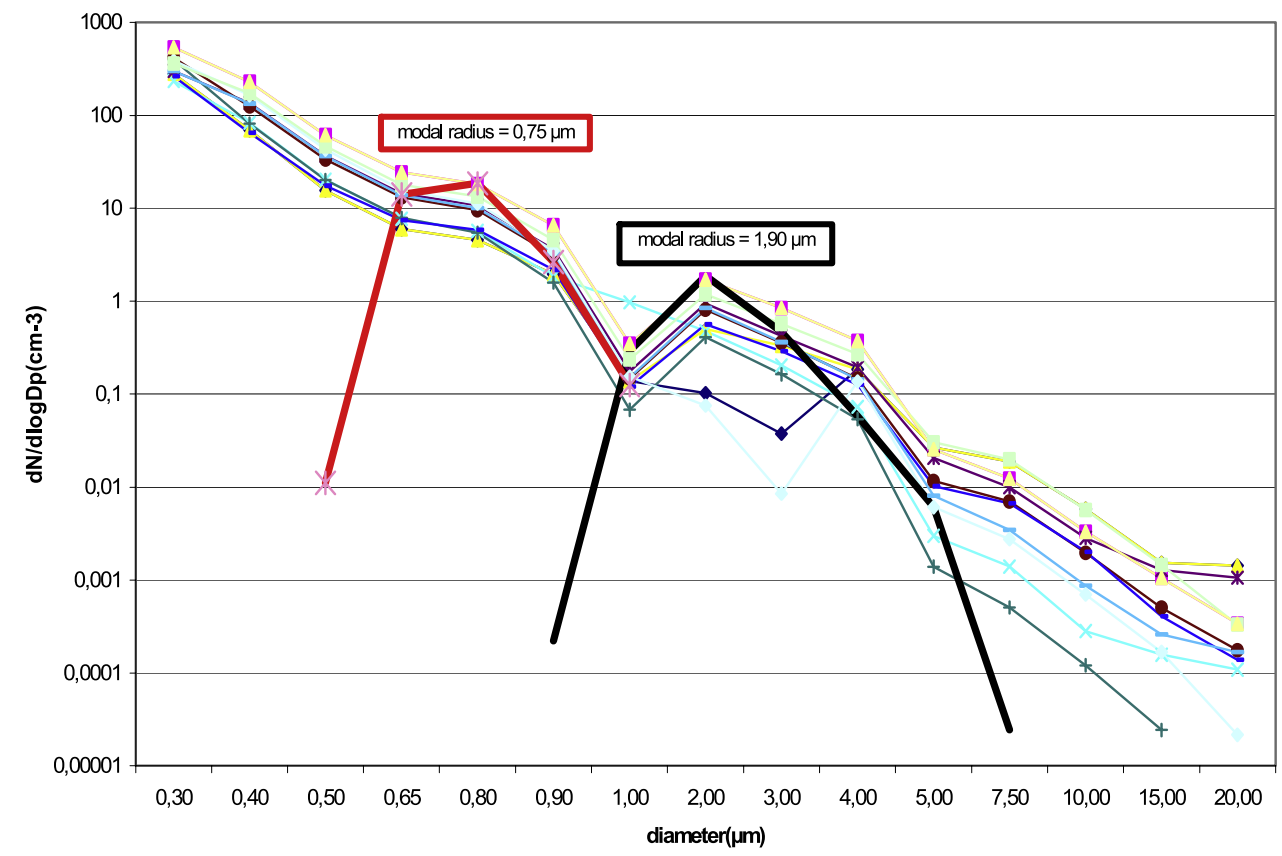

Figure 5. Aerosol number size distribution measured with GRIMM at Djougou during the 1724 January period. 


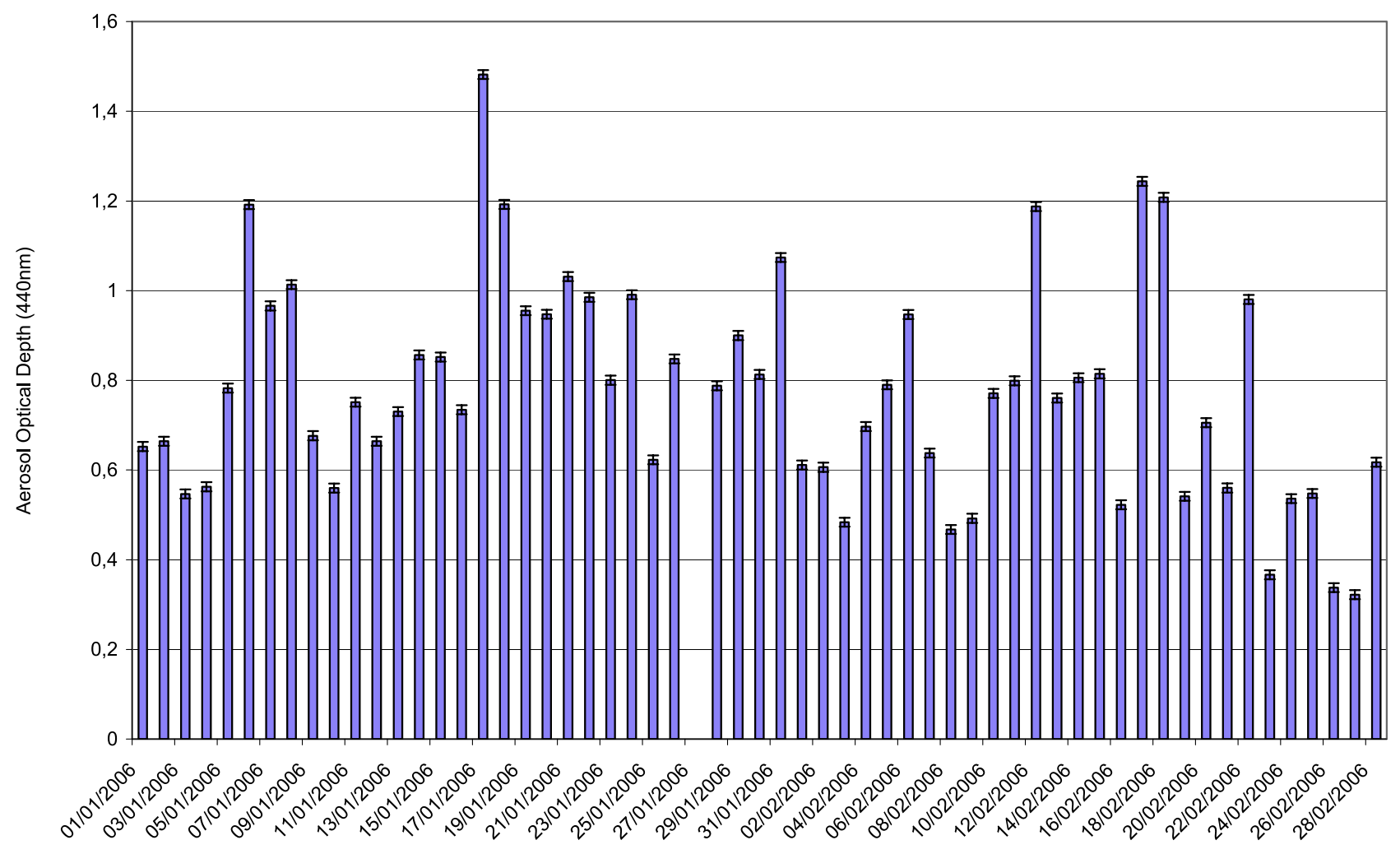

Figure 6. Aerosol optical depth (AOD) retrieved at $440 \mathrm{~nm}$ from Sun photometer measurements (PHOTON/LOA) at Djougou during the January-February 2006 period. Vertical bars show uncertainty $( \pm 0.01)$ in AOD measurements.

a total correction factor $\left(C_{\text {corr }}\right)$ ranging between 1.08 and 1.05 (450 and $700 \mathrm{~nm}$ ) for biomass burning aerosols, characterized by a modal diameter around $0.15 \mu \mathrm{m}$. Finally, Mallet et al. [2005] reported $C_{\text {corr }}$ of 1.10 for urban/ industrial submicronic aerosols.

[20] In numerous studies, $C_{\text {corr }}$ is usually estimated from the wavelength dependence of light scattering, as measured by the TSI 3-wavelength nephelometer, based on the work of Anderson and Ogren [1998]. In case of a single channel nephelometer, as the ECOTECH one used in our study, the spectral dependence of scattering is unavailable. Consequently, in order to correct scattering coefficients at Djougou, an alternative method has been adapted. First, the aerosol size distribution has been estimated from Differential Mobility Analyzer and GRIMM analyses. Then, a correction factor deduced from the literature [Heintzenberg et al., 2006] has been applied.

[21] At Djougou, the aerosol number size distribution was determined using a Vienna type medium size DMA, connected to a Condensation Particle Counter (TSI model 3010), plus a GRIMM. Results from DMA, averaged for one day, are reported in the Figure 3 . We can clearly observe that number size distributions (for $D_{p}<0.5 \mu \mathrm{m}$ ) are monomodal during the dry season, with the presence of a fine mode around $0.1 \mu \mathrm{m}$. It should be noted here that a good agreement (Figure 4) has been found with Passive Cavity Aerosol Spectrometer Probe (PCASP) measurements performed on board the BAe 146 aircraft for the passage over Djougou (altitude of $500 \mathrm{~m}$ ) for 19 January. Associated with DMA, the GRIMM measurements (Figure 5) indicated two other modes, with an accumulation (mode diameter of
$0.8 \mu \mathrm{m}$ ) and a coarse one (mode diameter of $2 \mu \mathrm{m}$ ). However, their concentrations are significantly lower compared to the fine mode and the corrections needed on nephelometer measurements are expected to be low. Hence, we considered in this work a correction factor $\left(C_{\text {corr }}\right)$ of 1.10 in our computations [Heintzenberg et al., 2006] and we assumed a $10 \%$ error in $b_{\text {scat }}$ [Formenti et al., 2002].

\section{Results and Discussion}

[22] As mentioned in the introduction, radiative transfer computations depend on several aerosol optical parameters such as the spectral variation of the AOD (see section 4.1.1), SSA (see sections 4.1.2 and 4.1.3) and asymmetry parameter (see section 4.1.4). Two methods for estimating SSA are used in this study. The first one (see section 4.1.2) uses measurements of the scattering and absorption coefficients, providing SSA at one wavelength $(520 \mathrm{~nm})$. The second method (see section 4.1.3) uses measurements of the aerosol size distributions together with the refractive index and Mie theory. This latter method allows calculating SSA at different wavelengths. It should be noted that the effect of nonsphericity of dust leads to a low impact on the asymmetry parameter [Bellouin et al., 2004], which is used as input in our radiative transfer model.

\subsection{Aerosol Optical Properties}

\subsubsection{Aerosol Optical Depth}

[23] Results of Sun photometer measurements obtained in January-February 2006 are presented in Figure 6, where daily mean $\mathrm{AOD}$ at $440 \mathrm{~nm}\left(\mathrm{AOD}_{440}\right)$, with associated 


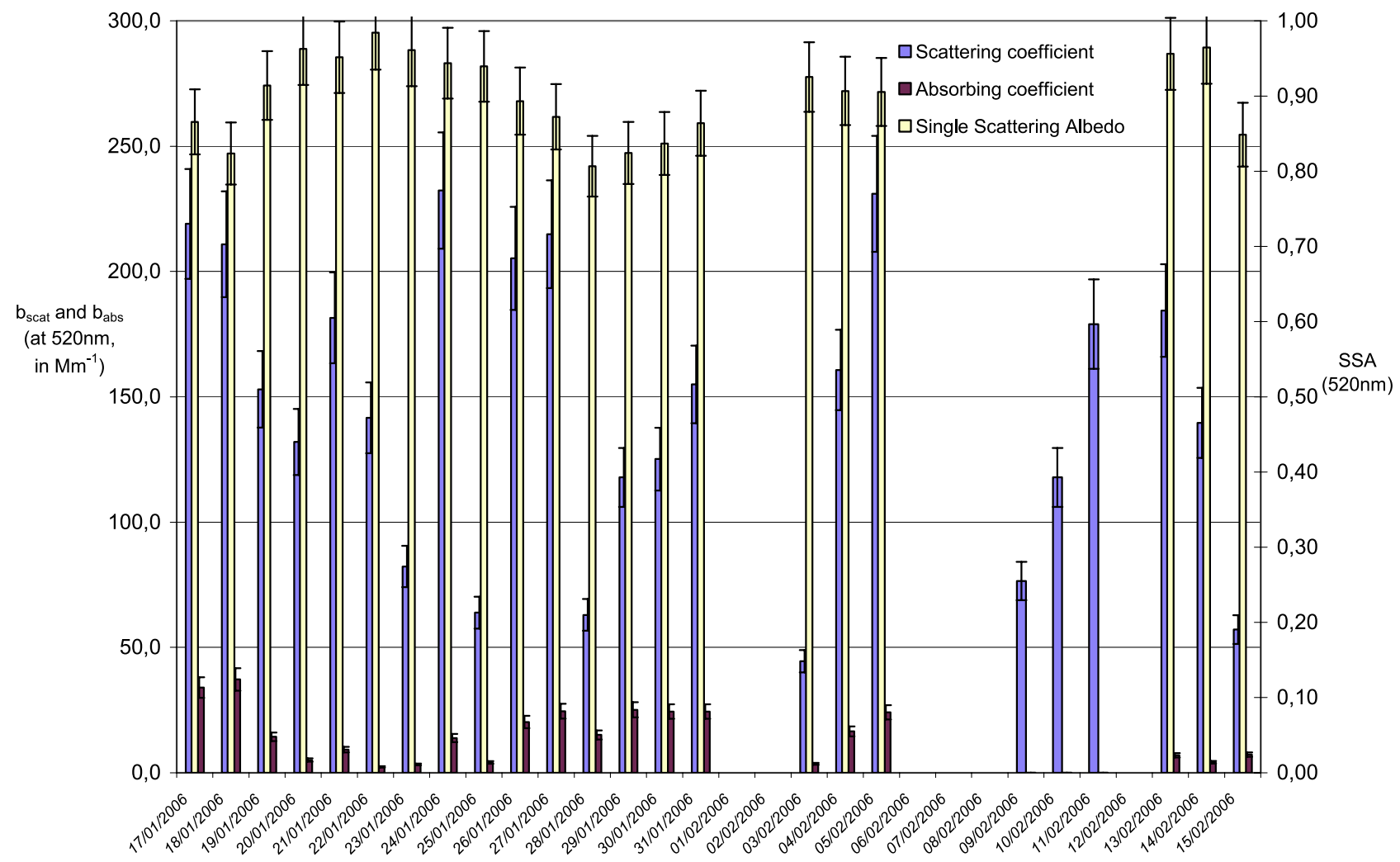

Figure 7. Aerosol absorbing, scattering coefficient, and single scattering albedo (SSA) estimated at $520 \mathrm{~nm}$ from aethalometer and nephelometer measurements. Vertical bars show error $( \pm 12, \pm 10$, and $\pm 5 \%)$ on the absorbing, scattering, and SSA calculations.

uncertainty in AOD [Holben et al., 1998] also shown. Although a much smaller amount of mineral dust has been observed during 2006, compared to previous years, Djougou atmosphere was rather turbid with $\mathrm{AOD}_{440}$ exceeding 0.5 for $90 \%$ of the days during January and February. The mean (and standard deviation) $\mathrm{AOD}_{440}$ during this period is $0.78 \pm 0.24$, indicating a significant aerosol loading. Very high $\mathrm{AOD}_{440}$ is observed for 17 and 18 January, with daily mean values of 1.5 and 1.1 .

[24] A way to know which kind of aerosols is present is to compute the Angström exponent $(\alpha)$, which represents the spectral variation of AOD. This optical parameter can help to infer the aerosol type (e.g., whether it is anthropogenic or dust-like) because of the dependency of $\alpha$ on particle size. For coarse aerosols, such as dust, $\alpha$ is close to 0 and for submicron particles (such as biomass burning or urban/ industrial), $\alpha$ is often between 1 and 2. It can be computed from the following relation:

$$
\alpha \lambda 1 / \lambda 2=-\log (\operatorname{AOD} \lambda 1 / \operatorname{AOD} \lambda 2) / \log (\lambda 1 / \lambda 2),
$$

where $\lambda 1$ and $\lambda 2$ represent the wavelength range over which $\alpha$ is calculated. The Angström exponent is commonly computed between 440 and $870 \mathrm{~nm}$. Over Djougou, the mean value of $\alpha_{440 / 870}$ is $1.00 \pm 0.21$ over the total atmospheric column. This value is found to be lower than those observed from photometer measurements for pure smoke [Dubovik et al., 2002], revealing a possible mixing between fine smoke particles and mineral dust over the column. This result is in agreement with the aerosol size distribution measured at Djougou, indicating the presence of fine and accumulation (expected to be smoke) modes [Haywood et al., 2003], and a coarse mode (expected to be mineral dust).

\subsubsection{Determination of Aerosol Single Scattering} Albedo From Absorbing and Scattering Coefficients

[25] The absorption coefficient measured at $520 \mathrm{~nm}$ $\left(b_{\mathrm{abs}(520)}\right)$ is presented in Figure 7 . Results show that $b_{\mathrm{abs}(520)}$ ranged from 2.3 to $37.3 \mathrm{Mm}^{-1}$ with an average (and standard deviation) for the overall period of $15.2 \pm$ $10.6 \mathrm{Mm}^{-1}$. For comparisons, $b_{\mathrm{abs}}$ is found to be generally lower than those observed by Chand et al. [2006] during the SMOCC experiment, which took place over the Amazon Basin from 16 September to 14 November in 2002. Chand et al. [2006] reported $b_{\mathrm{abs}}$ comprised between 1 and $70 \mathrm{Mm}^{-1}$ (the average value was not indicated). In parallel, the average value obtained in this work is comparable to $b_{\text {abs }}$ values obtained over the Indian Ocean during INDOEX (16 \pm $8 \mathrm{Mm}^{-1}$ from Mayol-Bracero et al. [2002]) and significantly higher to values reported during ACE-Asia for polluted aerosols (8.6 Mm$~^{-1}$ from Anderson et al. [2003]) or ACE-2 (8.9 Mm $\mathrm{Mm}^{-1}$ from Öström and Noone [2000]).

[26] The ambient scattering coefficient estimated at $520 \mathrm{~nm}$ is also presented in the Figure 7. The values from our measurements ranged from 44.5 to $232.3 \mathrm{Mm}^{-1}$, with a mean value (and standard deviation), for the overall period, of $145 \pm 59 \mathrm{Mm}^{-1}$. As mentioned above, this mean value is found to be lower than those reported by Chand et al. [2006] $\left(5-1435 \mathrm{Mm}^{-1}\right)$ during the SMOOC experiment. In parallel, our values are found to be significantly higher than 


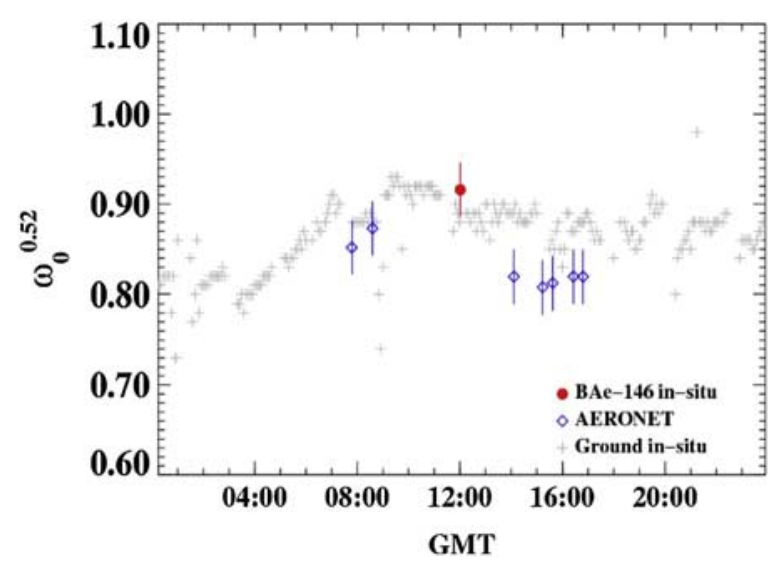

Figure 8. Comparisons between SSA measured at the surface, onboard the aircraft, and retrieved from AERONET at Djougou for 19 January.

those obtained during different field experiments, such as CLAIRE-98 (daily mean scattering coefficient of $26 \pm$ $8 \mathrm{Mm}^{-1}$ during dust outbreaks and $10 \mathrm{Mm}^{-1}$ for background level, [Formenti et al., 2001]), INDOEX (62 \pm $34 \mathrm{Mm}^{-1}$ [Mayol-Bracero et al., 2002]), ACE-Asia (55.3 $\mathrm{Mm}^{-1}$ [Anderson et al., 2003]), or ACE-2 (40 \pm $17 \mathrm{Mm}^{-1}$ [Quinn et al., 2000]).

[27] The temporal variation of ambient $\mathrm{SSA}_{520}$ (associated with an uncertainty of $\pm 5 \%$ [Formenti et al., 2002]) is reported in Figure 7 . We can observe values comprised between 0.81 and 0.98 , indicating high heterogeneity in SSA during the SOP-0, most probably because of variation in black carbon content of the aerosol. The mean value (and standard deviation), for the overall period, is $0.91 \pm 0.05$, indicating moderately absorbing particles. It should be mentioned here that a good agreement has been observed, for the 19 January, between SSA estimated at the surface $\left(\mathrm{SSA}_{520}=0.89\right)$ and that measured onboard the BAe 146 (Figure 8) aircraft $\left(\mathrm{SSA}_{520} \mathrm{BAe}=0.90\right)$. This result indicates a good level of confidence in our optical measurements and especially on the scattering correction used in the equation (7).

[28] For comparisons, our mean value is found to be higher than the one obtained by Eck et al. [2003] (mean of 0.84-0.85) and Leahy et al. [2007] $(0.85 \pm 0.02)$ during SAFARI 2000 and Eck et al. [2001] $(0.82-0.85 \pm 0.03)$ during the ZIMBBEE experiment. However, our value is found to be consistent with those reported by Eck et al.
[1998] (0.88 \pm 0.05 at $440 \mathrm{~nm})$ and Schafer et al. [2002] (median SSA between 0.89 and 0.91 at $440 \mathrm{~nm}$, with a standard deviation of 0.03), or Dubovik et al. [2002] (0.91 \pm 0.03 at $440 \mathrm{~nm}$ ) for biomass burning aerosols in Amazonia. Furthermore, our mean value is also consistent with the one reported by Chand et al. [2006] $(0.92 \pm 0.02)$ during the SMOCC experiment.

\subsubsection{Estimation of SSA From Number Size Distribution and Refractive Index}

[29] The aerosol number size distributions measured with the DMA (Figure 3) and GRIMM (Figure 5) have been fitted with lognormal functions. According to Putaud et al. [2000], the equivalent mobility diameter as measured by the DMA was considered to be equal to the geometric diameter, $D_{p}$. The main characteristics (number of particles, Geometric Mean Diameter (GMD) and Geometric Standard Deviation (GSD)) of the lognormal functions for the fine mode, obtained for each day, are reported in the Table 1 (the data are not available for 20 January). The averaged values indicate a total number concentration of $6100 \mathrm{~cm}^{-3}$, a GMD of $0.096 \mu \mathrm{m}$, and a GSD of 1.87. Associated with DMA measurements, those performed from GRIMM indicate two different modes, with one in the accumulation range (diameter of $0.8 \mu \mathrm{m}$ ) and another in the coarse range (diameter of $2 \mu \mathrm{m}$ ) for each day studied during the SOP-0.

[30] Concerning the fine mode, these characteristics are in the same order of values obtained by Rissler et al. [2006] in case of smoke particles produced over the Amazonian region during the dry season (GMD of $0.092 \mu \mathrm{m}$ and a GSD of 1.63). In terms of aerosol concentrations, Rissler et al. [2006] also reported a value of $5213 \mathrm{~cm}^{-3}$. In the review by Reid et al. [2005], median diameters between 0.10 and $0.13 \mu \mathrm{m}$ are reported for smoke from grass, savanna, cerrado, and forest burning. Finally, during the SMOCC field experiment, airborne measurements of particle size distribution have shown GMD of $0.11 \pm 0.01 \mu \mathrm{m}$ from 69 plumes within the boundary layer [Guyon et al., 2005].

[31] In addition to the aerosol number size distribution, the Mie theory requires the knowledge of the refractive index of particles. This information is not available from our measurements. Therefore, at Djougou, the imaginary part of the refractive index has been obtained by constraining SSA computed with Mie theory with SSA estimated using simultaneous measurements of absorption and scattering coefficients of particles (see the previous paragraph). In our computations, the real part of the refractive index is fixed to 1.54 [Haywood et al., 2003] for the fine and

Table 1. Number Concentration, Geometric Mean Diameter, and Geometrical Standard Deviation Obtained for the Lognormal Distribution Obtained From DMA and Associated Refractive Index (at $520 \mathrm{~nm}$ ) for the Fine and Accumulation Modes at Djougou

\begin{tabular}{ccccc}
\hline Date & $\begin{array}{c}\text { Number } \\
\text { Concentration }\left(\mathrm{cm}^{-3}\right)\end{array}$ & $\begin{array}{c}\text { Geometric Mean } \\
\text { Diameter }(\mathrm{nm})\end{array}$ & $\begin{array}{c}\text { Geometric Standard } \\
\text { Deviation }\end{array}$ & $\begin{array}{c}\text { Refractive Index } \\
\left(N_{520}-i K_{520}\right)\end{array}$ \\
\hline 17 Jan & 5604.88 & 115.11 & 1.83 & $1.54-i 0.025$ \\
18 Jan & 6391.38 & 112.13 & 1.81 & $1.54-i 0.032$ \\
19 Jan & 5089.36 & 85.94 & 1.95 & $1.54-i 0.015$ \\
21 Jan & 8486.32 & 99.39 & 1.86 & $1.54-i 0.008$ \\
22 Jan & 3927.54 & 74.71 & 1.95 & $1.54-i 0.001$ \\
23 Jan & 6085.47 & 87.99 & 1.85 & $1.54-i 0.005$ \\
24 Jan & 7119.26 & 100.17 & 1.86 & $1.54-i 0.010$ \\
Mean & $\mathbf{6 1 0 0}$ & $\mathbf{9 6 . 4 9}$ & $\mathbf{1 . 8 7}$ & $\mathbf{1 . 5 4}-\boldsymbol{i} 0.014$ \\
\hline
\end{tabular}


Table 2. Aerosol SSA (Averaged Between 0800 and 1800 UTC), Estimated for Different Days at the Surface (at $520 \mathrm{~nm}$ ) From the Nephelometer and Aethalometer, at the Surface From Mie Theory (at Different Wavelengths) and for the Whole Atmospheric Column From AERONET Retrievals

\begin{tabular}{|c|c|c|c|c|c|c|c|c|c|c|}
\hline \multirow[b]{2}{*}{ Date } & \multirow{2}{*}{$\begin{array}{c}\text { Derived From } \\
\text { Nephelometer and } \\
\text { Aethalometer (Surface) } \\
\text { SSA }_{520}\end{array}$} & \multicolumn{5}{|c|}{$\begin{array}{c}\text { Derived From SMPS } \\
\text { and Mie Theory (Surface) }\end{array}$} & \multicolumn{4}{|c|}{$\begin{array}{c}\text { Derived From AERONET } \\
\text { (Whole Atmospheric Column) }\end{array}$} \\
\hline & & $\mathrm{SSA}_{440}$ & $\mathrm{SSA}_{550}$ & $\mathrm{SSA}_{670}$ & $\mathrm{SSA}_{870}$ & $\mathrm{SSA}_{1020}$ & $\mathrm{SSA}_{440}$ & $\mathrm{SSA}_{670}$ & $\mathrm{SSA}_{870}$ & $\mathrm{SSA}_{1020}$ \\
\hline 17 Jan & 0.87 & 0.88 & 0.87 & 0.88 & 0.88 & 0.87 & 0.82 & 0.85 & 0.85 & 0.86 \\
\hline 18 Jan & 0.85 & 0.85 & 0.85 & 0.85 & 0.85 & 0.84 & 0.82 & 0.82 & 0.82 & 0.82 \\
\hline 19 Jan & 0.91 & 0.91 & 0.91 & 0.90 & 0.90 & 0.90 & 0.84 & 0.86 & 0.85 & 0.86 \\
\hline 21 Jan & 0.95 & 0.95 & 0.95 & 0.95 & 0.94 & 0.93 & 0.87 & 0.90 & 0.91 & 0.91 \\
\hline 22 Jan & 0.98 & 0.98 & 0.98 & 0.97 & 0.97 & 0.96 & 0.86 & 0.86 & 0.85 & 0.85 \\
\hline 23 Jan & 0.96 & 0.96 & 0.96 & 0.95 & 0.94 & 0.94 & 0.85 & 0.89 & 0.89 & 0.90 \\
\hline 24 Jan & 0.94 & 0.96 & 0.94 & 0.95 & 0.94 & 0.94 & 0.88 & 0.91 & 0.92 & 0.93 \\
\hline
\end{tabular}

accumulation modes and 1.53 [Osborne et al., 2008] for the coarse mode. Concerning the imaginary part, the value is fixed to 0.0004 [Osborne et al., 2008] for the coarse mode (expected to be mineral aerosol) and we adjust this for fine and accumulation modes. As reported in the Table 1, the imaginary part of the refractive index for the fine and accumulation modes is varies between 0.001 and 0.032 , with a mean of 0.014 (at $520 \mathrm{~nm}$ ). For comparison, this average value obtained at Djougou is in reasonable agreement with the one reported by Haywood et al. [2003] (0.018 at $550 \mathrm{~nm}$ ) for aged biomass burning plumes.

[32] Using the aerosol size distribution and refractive index, SSA has been computed at the seven wavelengths (Table 2) used in the GAME radiative transfer model. The values reported in Table 2 show no significant dependence of SSA with wavelengths, a result that is similar with the SSA spectral variation observed from AERONET retrievals. In parallel, it should be noted that comparisons between SSA estimated at the surface (at $440 \mathrm{~nm}$ ) and those retrieved from AERONET show large differences (Table 2 and Figure 8), with AERONET retrievals generally smaller. Such differences are due to the presence of the elevated biomass burning layer, characterized by lower SSA (B. Johnson et al., Aircraft measurements of biomass-burning aerosols over West Africa during DABEX, submitted to Journal of Geophysical Research, 2007). In this work, we took advantage of SSA obtained from in situ measurements (at the surface and in the BBL) for calculating a column mean by weighting the run means by the contribution of each layer to the total aerosol optical depth. This method provides better comparisons with AERONET, especially for the 21-24 January period (Table 2), with column mean values around 0.90 at $440 \mathrm{~nm}$ (SSA from AERONET is about 0.85-0.87).

\subsubsection{Aerosol Asymmetry Parameter}

[33] The asymmetry parameter has been computed at different wavelengths from Mie theory following the same methodology described above for SSA. As shown in the Table 3 , the asymmetry parameter varied between 0.64 and 0.67 range (at $520 \mathrm{~nm}$ ), with a mean (and standard deviation) of $0.66 \pm 0.01$. As observed for SSA, no significant dependence of $g$ with wavelengths is noted and agreement is found with AERONET observations. When we calculate $g$ for the whole atmospheric column (as mentioned above for SSA), comparisons are found consistent with a mean of 0.64 and 0.69 (at $440 \mathrm{~nm}$ ) from in situ and AERONET calculations, respectively. Finally, it should be noted that our calculations are consistent with those reported by Procopio et al. [2004] for smoke aerosols with values ranging from 0.64 to 0.67 (at $440 \mathrm{~nm}$ ).

\subsection{Radiative Forcing}

[34] The clear sky direct radiative forcing over Djougou has been estimated from the GAME radiative transfer model, detailed by Dubuisson et al. [2004]. GAME accounts for the scattering and absorption processes by particles and gases. Gaseous absorption $\left(\mathrm{H}_{2} \mathrm{O}, \mathrm{CO}_{2}, \mathrm{O}_{2}\right.$, and $\mathrm{O}_{3}$ ) is treated from the correlated $k$ distribution, using a line by line code [Dubuisson et al., 1996] and multiple scattering effects are treated using the Discrete Ordinates Method (DOM) [Stamnes et al., 1988]. This method allows accurate treatment of scattering and absorption by aerosols, clouds, and molecules.

[35] Upward and downward net radiative fluxes are calculated over the solar spectrum, ranging from 2500 to $50000 \mathrm{~cm}^{-1}$, with a $100 \mathrm{~cm}^{-1}$ spectral resolution. Calculations of radiative fluxes integrated over the entire shortwave region are performed at every $1 \mathrm{~h}$ interval and for a $24 \mathrm{~h}$ period. From these fluxes, we computed the aerosol clear sky daily direct forcing at the bottom of atmosphere (BOA), $\Delta F_{\mathrm{BOA}}$, and at the top of the atmosphere (TOA) (70 km in this case), $\Delta F_{\mathrm{TOA}}$. The first one represents the effect of particles on the net short-wave radiation fluxes reaching the surface and the second one the radiation fluxes reflected back to space by aerosols. BOA and TOA forcings have been calculated as following:

$$
\begin{aligned}
\Delta F_{\mathrm{BOA}} & =F_{\mathrm{BOA}(w)} \downarrow-F_{\mathrm{BOA}(\mathrm{o})} \downarrow \\
\Delta F_{\mathrm{TOA}} & =-\left(F_{\mathrm{TOA}(w)} \uparrow-F_{\mathrm{TOA}(\mathrm{o})} \uparrow\right),
\end{aligned}
$$

where $F_{\mathrm{BOA}(w) \downarrow}$ and $F_{\mathrm{BOA}(o) \downarrow} \downarrow$ are, respectively, the downward net radiative fluxes simulated at the surface with $(w)$ and without $(o)$ aerosols. $F_{\mathrm{TOA}(w)} \uparrow$ and $\mathrm{F}_{\mathrm{TOA}(o)} \uparrow$ are, respectively, the upward net radiative fluxes simulated at the top of atmosphere with $(w)$ and without $(o)$ aerosols. With this convention, a negative sign of $\Delta F$ implies an aerosol cooling effect. Finally, as reported by Roger et al. [2006], we compute the atmospheric forcing, $\Delta F_{\mathrm{ATM}}$, by using the following relation:

$$
\Delta F_{\mathrm{ATM}}=\Delta F_{\mathrm{TOA}}-\Delta F_{\mathrm{BOA}}
$$


Table 3. Aerosol Asymmetry Parameter Estimated at the Surface (at Different Wavelengths) From Mie Theory and for the Whole Atmospheric Column From AERONET Retrievals

\begin{tabular}{|c|c|c|c|c|c|c|c|c|c|}
\hline \multirow[b]{2}{*}{ Date } & \multicolumn{5}{|c|}{$\begin{array}{c}\text { Derived From SMPS } \\
\text { and Mie Theory (Surface) }\end{array}$} & \multicolumn{4}{|c|}{$\begin{array}{c}\text { Derived From AERONET } \\
\text { (Whole Atmospheric Column) }\end{array}$} \\
\hline & $g_{440}$ & $g_{550}$ & $g_{670}$ & $g_{870}$ & $g_{1020}$ & $g_{440}$ & $g_{670}$ & $g_{870}$ & $g_{1020}$ \\
\hline 17 Jan & 0.68 & 0.66 & 0.65 & 0.63 & 0.64 & 0.67 & 0.65 & 0.66 & 0.68 \\
\hline 18 Jan & 0.67 & 0.66 & 0.65 & 0.64 & 0.63 & 0.66 & 0.65 & 0.65 & 0.66 \\
\hline 19 Jan & 0.68 & 0.67 & 0.66 & 0.66 & 0.68 & 0.67 & 0.62 & 0.62 & 0.63 \\
\hline $21 \mathrm{Jan}$ & 0.65 & 0.64 & 0.63 & 0.62 & 0.61 & 0.71 & 0.68 & 0.69 & 0.70 \\
\hline $22 \mathrm{Jan}$ & 0.68 & 0.67 & 0.66 & 0.66 & 0.68 & 0.71 & 0.67 & 0.67 & 0.68 \\
\hline 23 Jan & 0.67 & 0.66 & 0.66 & 0.67 & 0.65 & 0.71 & 0.67 & 0.68 & 0.69 \\
\hline $24 \mathrm{Jan}$ & 0.67 & 0.66 & 0.64 & 0.63 & 0.65 & 0.71 & 0.69 & 0.70 & 0.72 \\
\hline
\end{tabular}

$\Delta F_{\text {ATM }}$ represents the possible absorption of solar radiation due to absorbing particles within the atmospheric specified aerosol layers.

\subsection{Aerosol Vertical Profiles}

[36] As reported by Ganguly and Jayaraman [2006], an important point for estimating the direct forcing of aerosols is their vertical profile within the atmosphere. Indeed, numerous studies [Haywood and Ramaswamy, 1998; Chung et al., 2005] indicate that one major contributor to the uncertainty in atmospheric forcing comes from uncertainty in the vertical distribution of aerosols. Differences in vertical profiles affect the distribution of forcing within the atmosphere and can produce different patterns in terms of cooling or heating depending on the altitude of the different aerosol layers.

\subsubsection{Vertical Profiles of Aerosol Extinction}

Coefficient

[37] In order to take into account the vertical profiles of aerosol extinction in GAME, we have used a MPL, operating at Djougou and administered by the Service d'Aéronomie (SA). Once corrected from signal saturation and geometrical factor, the attenuated profiles are inverted to retrieve extinction coefficient profiles, $\alpha_{e}$ at $532 \mathrm{~nm}$ [Pelon et al., 2008]. Figure 9 shows an example of extinction coefficient (in $\mathrm{km}^{-1}$ ) profiles obtained at Djougou for 21 January (the shape of the vertical profile is similar to those obtained during all of SOP-0, Pelon et al. [2008]). The first aerosol layer is around $0.5 \mathrm{~km}$ and characterized by extinction coefficients

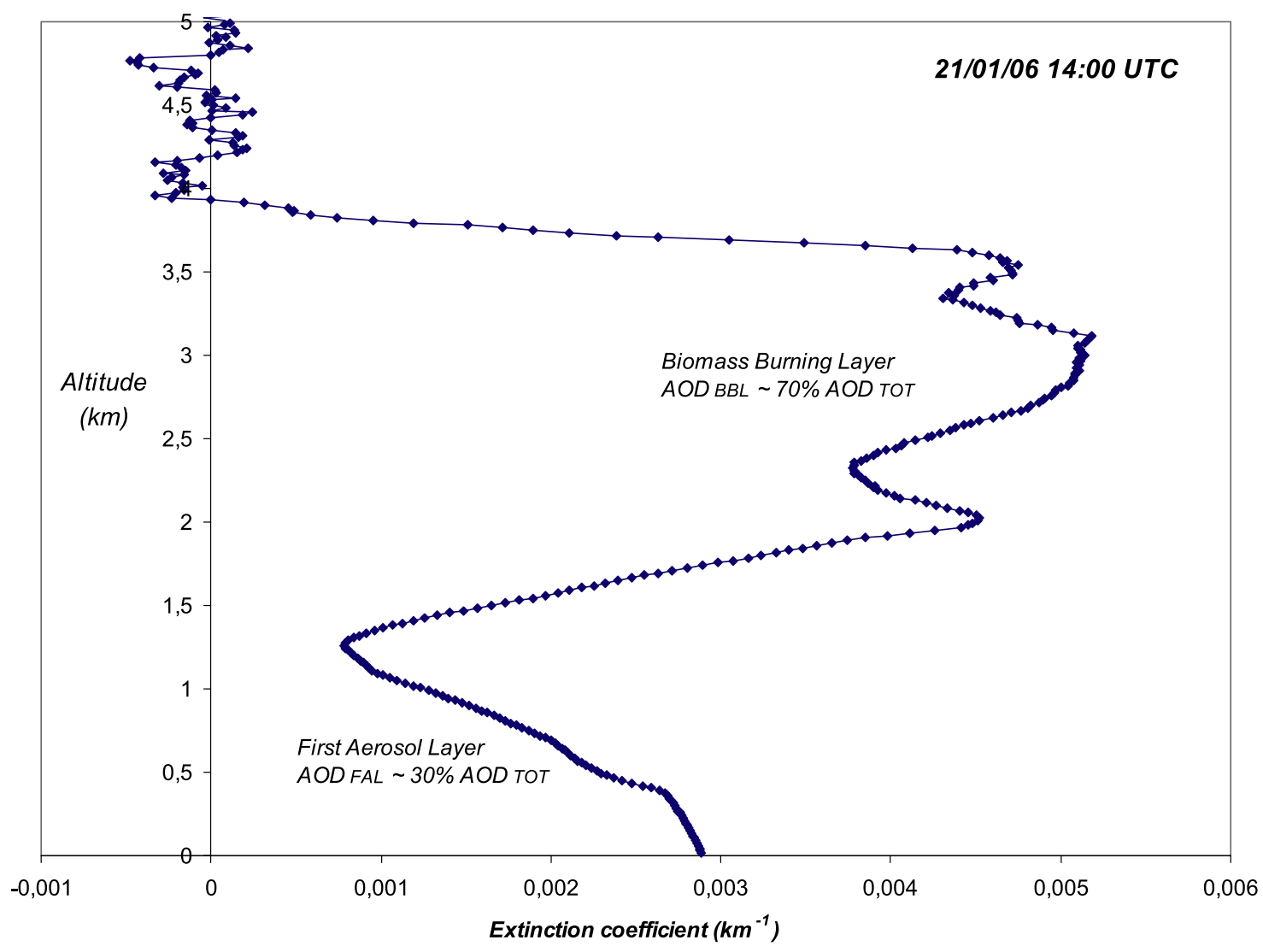

Figure 9. Profile of micropulse lidar aerosol extinction coefficient obtained at Djougou for 21 January 2006. 
Table 4. Dry Mie-Derived Single Scattering Albedo and Asymmetry Parameter as Reported by B. Johnson et al. (submitted manuscript, 2007) From BAe 146 Aircraft Measurements

\begin{tabular}{lccc}
\hline & \multicolumn{3}{c}{ Wavelengths (nm) } \\
\cline { 2 - 4 } & 450 & 550 & 670 \\
\hline SSA & 0.86 & 0.84 & 0.81 \\
$g$ & 0.62 & 0.57 & 0.49 \\
\hline
\end{tabular}

around $0.15 \mathrm{~km}^{-1}$, following by a rapid decrease of $\alpha_{e}$ between 0.5 and $1 \mathrm{~km}$. Above $1 \mathrm{~km}$, we can observe a second aerosol layer, with $\alpha_{e}$ of $0.3 \mathrm{~km}^{-1}$, for altitudes comprised between 1500 and $4000 \mathrm{~m}$, assumed to be composed mainly of biomass burning aerosols (B. Johnson et al., submitted manuscript, 2007). MPL measurements show clearly the significant contribution of the biomass burning layer (BBL) to the total AOD (around 70\%) and the smaller contribution of the lower aerosol layer to the total AOD (around 30\%), indicating that a large part of the solar extinction at Djougou is due to the BBL.

\subsubsection{Vertical Profiles of Aerosol SSA and $g$}

[38] Associated with the aerosol extinction profiles, SSA and $g$ vertical profiles were obtained by combining our measurements at the surface with aircraft observations and data from the literature. Briefly, the spectral variation of SSA and $g$ computed at the surface (Tables 2 and 3) are used as input for the first aerosol layer. Concerning the BBL, we considered the spectral variation of dry SSA and $g$ obtained onboard the BAe 146 by (B. Johnson et al., submitted manuscript, 2007) for biomass burning aerosols. These estimates have been obtained by using TSI nephelometer and Particle Soot Absorption Photometer (PSAP) measurements, for estimating scattering and absorption coefficients. In addition, Mie calculations have been also used to derive extinction coefficients, asymmetry parameters and angstrom exponents. Optical properties reported by (B. Johnson et al., submitted manuscript, 2007) for aged biomass burning aerosols and used as input in GAME are shown in the Table 4. Finally, to complete the vertical stratification, the spectral variation of optical properties coming from the aerosol models described by Hess et al. [1998] has been used for the free troposphere and stratosphere.

[39] As reported in section 3, no corrections on optical and microphysical properties due to $\mathrm{RH}$ have been taking into account in the lower aerosol layer (expected for $\mathrm{RH}$ larger than 40\%). Concerning the $\mathrm{BBL}$, aircraft measurements indicate that $\mathrm{RH}$ higher than $50 \%$ has been observed (as shown in the Figure 10 for 19 January). In such cases, dry optical properties (in particular scattering) need accurate corrections to take into account variations with RH. In our calculations, these corrections have been made for all cases by using the values of $a$ and $b$ (relation 6) from Magi and Hobbs [2003] for ambient smoke samples $(a=1.31$ $(0.08$ and $b=4.88(0.28)))$. As an example of results, for 19 January, dry to wet SSA changes from 0.86 to 0.90 (at $450 \mathrm{~nm}$ ).

[40] Finally, in order to correct the asymmetry parameter with RH in the BBL, we have used the microphysical properties $(\mathrm{GMD}=0.24 \mu \mathrm{m} / \mathrm{GSD}=1.30)$ and refractive index $(1.54-0.035 i)$ reported in dry state by B. Johnson et al. (submitted manuscript, 2007). GMD has been calculated in the ambient state from a growth factor of 1.24 [Rissler et al., 2006], corresponding to moderately hygroscopic biomass burning aerosols observed in South America (during the dry season). To finalize our Mie computations, the refractive index has been computed at ambient $\mathrm{RH}$ using the relation described by Mallet et al. [2003]. As an example of results, our calculations indicate a change in $g$ from 0.58 (at $550 \mathrm{~nm}$ ) in dry state to 0.65 at $85 \% \mathrm{RH}$ for 19 January.

\subsection{Vertical Profiles of Atmospheric Properties}

[41] RH and temperature vertical profiles used in GAME have been measured onboard the BAe 146 aircraft for 19 January. We completed the stratification, for altitudes greater than $4 \mathrm{~km}$, by using data available in the Shadoz network [Thompson et al., 2003]. Ozone concentration profiles have been determined by combining ground-based measurements performed at Djougou with the Shadoz [Thompson et al., 2003] measurements carried out on Cotonou (Southern Benin) for the upper atmosphere.

\subsection{Surface Albedo}

[42] As the estimation of radiative forcing has been performed over land, surface reflection is an issue. As reported by Roger et al. [2006], we used the MODIS albedo product (MODIS/Terra Albedo; 16-Day; Level-3 Global $1 \mathrm{~km}$ SIN Grid), which provides the spectral dependence of surface albedo over seven wavelength bands. Such information has been used as input in GAME to reproduce the surface albedo for the entire shortwave range. In our computations, a constant surface albedo has been considered for the whole month of January 2006. At $550 \mathrm{~nm}$, the surface albedo at Djougou is equal to $0.20 \pm 0.06$.

\subsection{Error Budget}

[43] Here we performed some sensitivity tests (summarized in Table 5), considering uncertainties on aerosol optical properties (for the two aerosol layers), together with the surface albedo. We apply $\pm 5 \%$ on the SSA, $g$ and

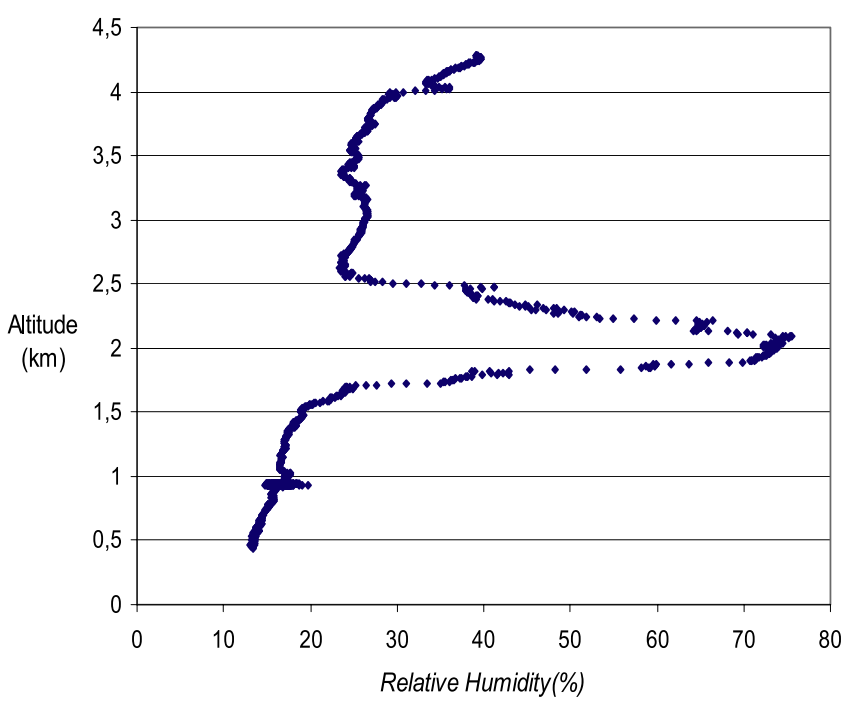

Figure 10. Relative humidity profile obtained from the BAe 146 aircraft on 19 January. 
Table 5. Error Budget (Simulated at Noon) on the Determination of the Aerosol Direct Forcing Including Optical Parameters of Aerosols as Measured at the Surface and in the Biomass Burning Layer and the Surface Albedo

\begin{tabular}{lccc}
\hline & $\Delta F_{\mathrm{BOA}}(\%)$ & $\Delta F_{\mathrm{TOA}}(\%)$ & $\Delta F_{\mathrm{ATM}}(\%)$ \\
\hline SSA surf $\pm 5 \%$ & 2.3 & 3.2 & 3.2 \\
SSA BBL $\pm 5 \%$ & 7.3 & 24 & 12.7 \\
$g$ surf $\pm 5 \%$ & 0.5 & 1.9 & 0.3 \\
$g$ BBL $\pm 5 \%$ & 2.3 & 11.5 & 0.7 \\
Surface Albedo $\pm 5 \%$ & 0.4 & 9.1 & 1.8 \\
\hline
\end{tabular}

surface albedo. Results of induced uncertainties are given in percentage in Table 5, showing values comprised between 0.5 and $7 \%, 3.2$ and $24 \%, 0.3$ and $12.7 \%$ for BOA, TOA, and atmosphere (ATM) forcings, respectively. As mentioned by Roger et al. [2006], the overall interpretation of all these uncertainties needs to account for the linked errors and counterbalancing effects. Consequently, we can reasonably consider that the daily radiative impacts of aerosols are defined here with an accuracy of $10 \%$ for BOA, $40 \%$ for TOA, and $15 \%$ for ATM. It should be noted that uncertainties reported here are larger (especially at TOA) than those obtained by Roger et al. [2006] because of the presence of the BBL (Table 5).

\subsection{Bottom of Atmosphere Direct Radiative Forcing}

[44] As shown in Figure 11, the downward fluxes simulated at the surface by GAME compared well with pyranometer measurements performed at Djougou. The normalized bias (in percentage) is equals to $-0.2 \%$ associated with a root mean square (RMS) of 25.6. As summarized in Table 6, our simulations indicate important surface radiative forcings for each day studied, with $\Delta F_{\mathrm{BOA}}$ (and associated errors) varying between $-43.8 \pm 4.4$ and -84.1 $\pm 8.4 \mathrm{~W} / \mathrm{m}^{2}$. Our simulations allow investigating the surface forcing during 17 and 18 January with high AOD (1.5 at $440 \mathrm{~nm}$ ). For these specific days, the instantaneous surface forcing estimated by GAME can reach up to $-240 \mathrm{~W} / \mathrm{m}^{2}$ and $-165 \mathrm{~W} / \mathrm{m}^{2}$, for 17 and 18 January, respectively (for a solar zenith angle of $30^{\circ}$ ). Such values are found to be very consistent with observations reported by Schafer et al. [2002] for biomass burning aerosols in the Zambian Savanna $(\mathrm{AOD}=1)$, with a reduction in total irradiance at the surface of $210 \mathrm{~W} / \mathrm{m}^{2}$ (mean solar zenith angle of $31^{\circ}$ ).

[45] In order to extend our simulations for a more representative period, we have used the mean $\mathrm{BOA}$ forcing efficiency (Table 6), obtained between 17 and 24 January, with AOD measured during all the dry season (Figure 6). Results are indicated in the Figure 12. The mean (and standard deviation) value obtained during the dry season period is $-45 \pm 14 \mathrm{~W} / \mathrm{m}^{2}$. For comparisons, the calculated daily surface forcing at Djougou is found to be consistent with those simulated by Procopio et al. [2004], who reported monthly averaged values (during the dry season) ranging from -21 to $-74 \mathrm{~W} / \mathrm{m}^{2}$ for two locations in the Amazon region (Alta Floresta and Abracos Hill), heavily impacted by biomass burning aerosols. Our simulations are found to be comparable with those obtained during INDOEX $\left(-45 \mathrm{~W} / \mathrm{m}^{2}\right)$ by Ramanathan et al. [2001] and Léon et al. [2002].

[46] It is clear that such significant decrease of solar energy at the surface can strongly modify the surface energy budget. Indeed, under normal conditions, surface radiation flux is balanced by latent heat and sensible heat fluxes from the surface. In order to compensate for the reduction of surface solar flux, a decrease in heat flux from the surface may be expected. Feingold et al. [2005] and Jiang and Feingold [2006] have showed that the reduction in surface latent and sensible heat fluxes associated with biomass burning impact may reduce cloudiness over the Amazonia region. Consequently, and because of our high BOA values,

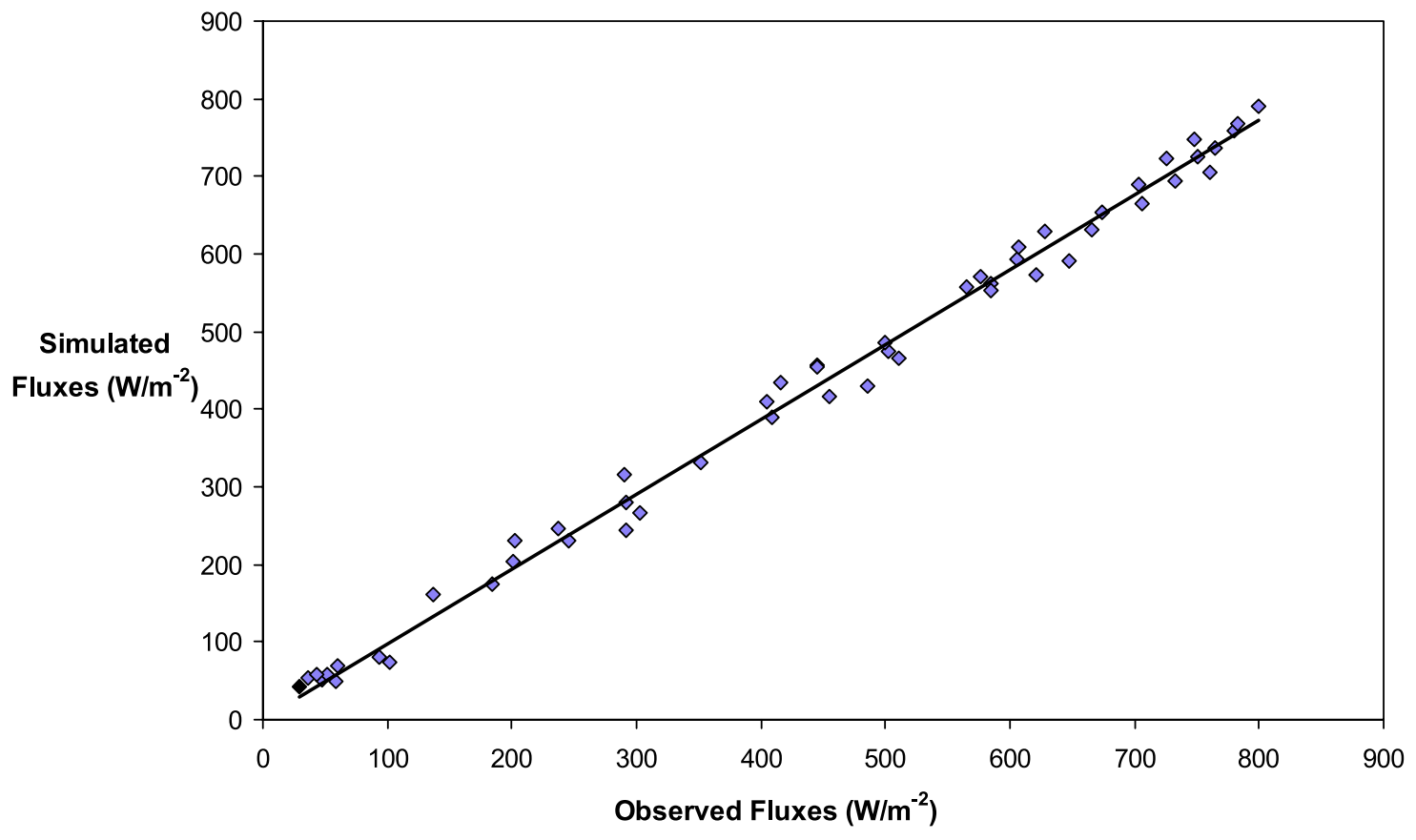

Figure 11. Comparison of observed versus modeled surface fluxes over Djougou. 
Table 6. AOD (at $440 \mathrm{~nm}$ ); Daily Clear Sky $\Delta \mathrm{F}$ and Daily Efficiency $\Delta \mathrm{FE}$ Direct BOA, TOA, and ATM Forcings; and Heating Rates Only due to Aerosols in The First Aerosol Layer (Averaged Between 0 and $1000 \mathrm{~m}$ ) and in the BBL (Averaged Between 1500 and $4000 \mathrm{~m})^{\mathrm{a}}$

\begin{tabular}{|c|c|c|c|c|c|c|c|c|c|}
\hline Date & $\mathrm{AOD}_{440}$ & $\Delta \mathrm{F}_{\mathrm{BOA}}$ & $\Delta \mathrm{F}_{\mathrm{TOA}}$ & $\Delta \mathrm{F}_{\mathrm{ATM}}$ & $\triangle \mathrm{FE}_{\mathrm{BOA}}$ & $\Delta \mathrm{FE}_{\mathrm{TOA}}$ & $\Delta \mathrm{FE}_{\mathrm{ATM}}$ & HER in FAL & HER in BBL \\
\hline 17 Jan & 1.48 & -84.1 & -23.2 & 60.9 & -56.8 & -15.7 & 41.1 & 2.08 & 3.27 \\
\hline 18 Jan & 1.19 & -61.6 & -15.6 & 45.9 & -51.7 & -13.1 & 38.6 & 2.20 & 1.76 \\
\hline 19 Jan & 0.96 & -55.7 & -14.8 & 40.9 & -58.0 & -15.4 & 42.6 & 1.16 & 1.62 \\
\hline 21 Jan & 1.03 & -69.5 & -20.9 & 48.5 & -67.4 & -20.3 & 47.1 & 0.66 & 2.07 \\
\hline 22 Jan & 0.99 & -62.8 & -19.4 & 43.4 & -63.4 & -19.6 & 43.8 & 0.93 & 1.44 \\
\hline $23 \mathrm{Jan}$ & 0.80 & -43.8 & -15.5 & 28.3 & -54.8 & -19.4 & 35.4 & 1.77 & 1.29 \\
\hline 24 Jan & 0.99 & -53.0 & -19.1 & 33.9 & -53.5 & -19.3 & 34.2 & 1.92 & 1.69 \\
\hline Mean & 1.06 & -61.5 & -18.4 & 43.1 & $-\mathbf{5 7 . 9}$ & -17.5 & 40.4 & 1.53 & 1.90 \\
\hline
\end{tabular}

${ }^{a}$ Daily clear sky $\Delta \mathrm{F}$ (and daily efficiency $\Delta \mathrm{FE}$ ) direct BOA, TOA, and ATM forcings given in $\mathrm{W} / \mathrm{m}^{2}$ (and given in $\mathrm{W} / \mathrm{m}^{2} / \mathrm{AOD}^{-1}$ ) and heating Rates given in $\mathrm{K} \mathrm{day}^{-1}$.

it is important to study the impact of aerosols on the surface energy budget over the West African region.

\subsection{TOA and Atmospheric Direct Radiative Forcing}

[47] GAME calculations of upward fluxes have been compared with broad band radiometer (BBR) flux measurements performed on board the BAe 146 aircraft for 19 January and satisfactory agreements have been obtained between the normalized upward fluxes simulated with GAME $\left(146 \mathrm{~W} / \mathrm{m}^{2}\right)$ and the one measured from the aircraft radiometer $\left(140 \mathrm{~W} / \mathrm{m}^{2}\right)$, for a solar angle of $30^{\circ}(1200 \mathrm{UTC})$. At Djougou, moderate or low $\Delta F_{\mathrm{TOA}}$ (Table 6) have been computed by GAME between 17 and 24 January, with values (and associated error) between $-14.8 \pm 5.9$ and $-23.2 \pm 9.3 \mathrm{~W} / \mathrm{m}^{2}$. The mean value (and standard devia- tion) is about $-18.4 \pm 3.1 \mathrm{~W} / \mathrm{m}^{2}$. After averaged during all the dry season (Figure 12), the TOA forcing indicates a mean (and standard deviation) value of $-13.6 \pm 4.2 \mathrm{~W} / \mathrm{m}^{2}$. For comparison, this value is found to be consistent with those obtained by Ross et al. [1998] $\left(-8 \pm 9<\Delta F_{\mathrm{TOA}}<\right.$ $-20 \pm 7 \mathrm{~W} / \mathrm{m}^{2}$ ) for the 1995 dry season in Amazonia, and slightly larger than those $\left(-5<\Delta F_{\mathrm{TOA}}<-12 \mathrm{~W} / \mathrm{m}^{2}\right)$ reported by Procopio et al. [2004].

[48] One of the most important results of this study concerns the large atmospheric forcings obtained at Djougou due to significant differences between $\Delta F_{\mathrm{TOA}}$ and $\Delta F_{\mathrm{BOA}}$. Our results indicated that $\Delta F_{\mathrm{TOA}}$ is 3.5 times lower than the mean $\Delta F_{\mathrm{BOA}}$. During the dry season (Figure 12), $\Delta F_{\mathrm{ATM}}$ (and associated errors) ranged from $13.1 \pm 1.9$ to $60.9 \pm 9.1 \mathrm{~W} / \mathrm{m}^{2}$, with a mean value (and standard devia-

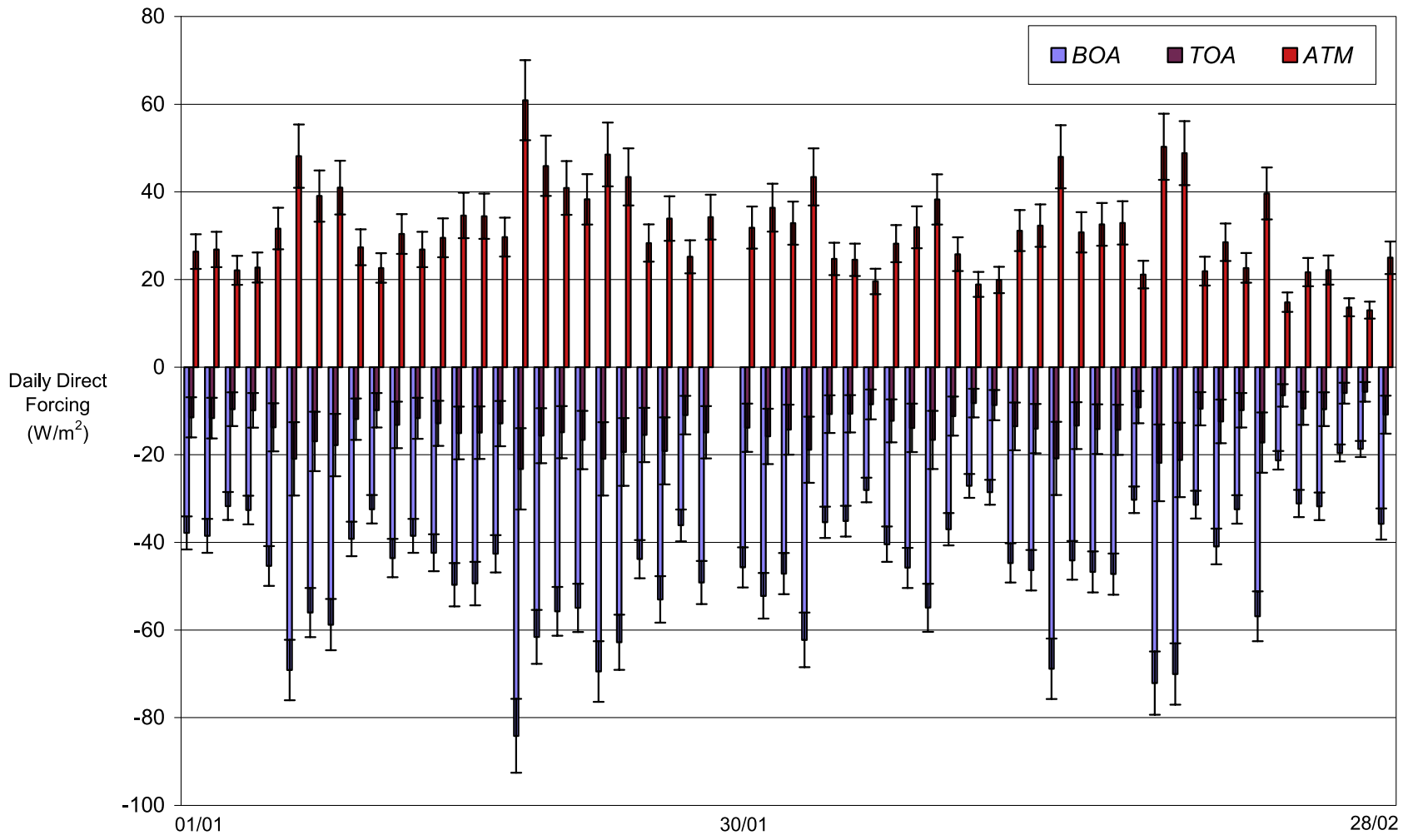

Figure 12. Aerosol clear sky daily direct radiative forcing (in $\mathrm{W} / \mathrm{m}^{2}$ ) estimated for 1 January to 30 February period at Djougou. Vertical bars show error $( \pm 12, \pm 20$, and $\pm 16 \%)$ on the BOA, TOA, and ATM forcings [Roger et al., 2006]. 


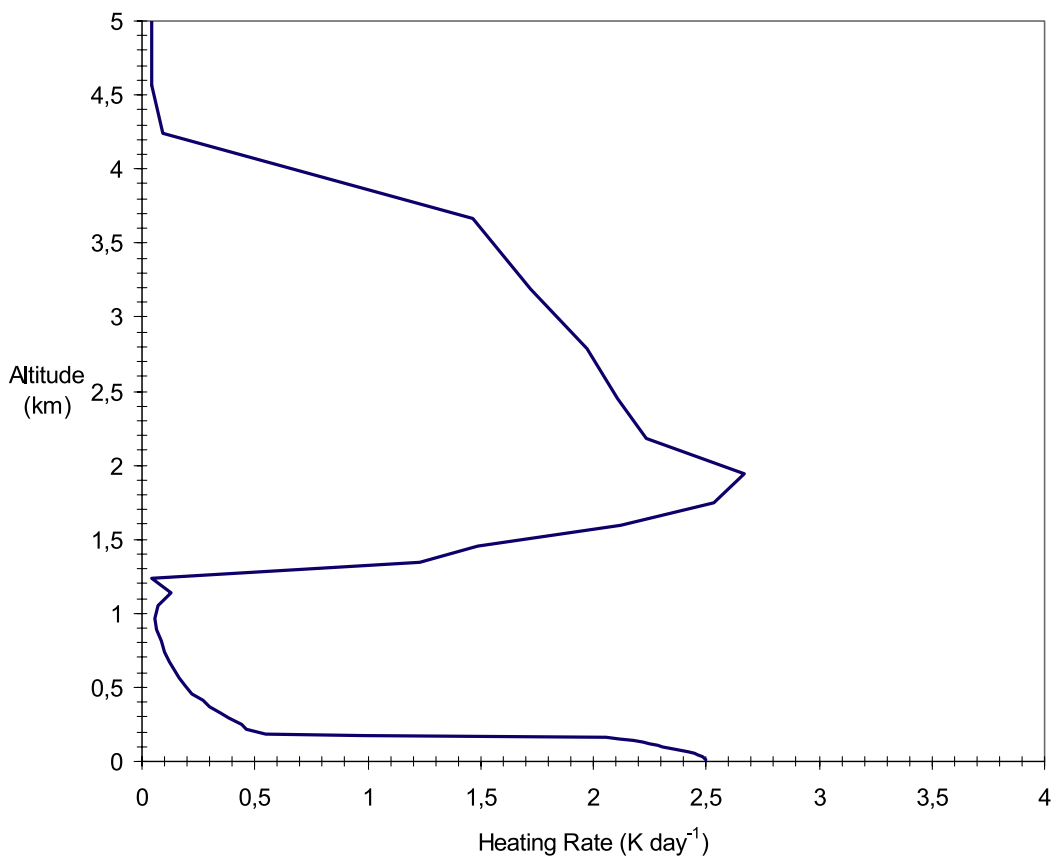

Figure 13. Mean vertical profiles of the predicted heating rate due only to the presence of aerosols between 17 and 24 January.

tion) of $31.4 \pm 10.0 \mathrm{~W} / \mathrm{m}^{2}$. Our results are consistent with those reported by Procopio et al. [2004], with $\Delta F_{\mathrm{ATM}}$ ranging from 16.2 to $61.7 \mathrm{~W} / \mathrm{m}^{2}$.

[49] As mentioned by Ganguly and Jayaraman [2006], although the large difference between the BOA and TOA forcing may indicate the absorption of solar radiation in the atmosphere, it is of great importance to investigate how this atmospheric heating is vertically distributed in the atmosphere. Indeed, several studies have shown that the atmospheric heating by absorbing particles may evaporate low-level clouds, resulting in a decrease of cloud cover and planetary albedo [Hansen et al., 1997; Ackerman et al., 2000]. For that purpose, vertical profile of the heating rate (HER in $\mathrm{K} \mathrm{day}^{-1}$ ) has been computed from GAME, as described by Roger et al. [2006]. The average vertical profile of the predicted HER, due only to the presence of aerosols, is reported in Figure 13 and the corresponding mean HER values, for the two main aerosol layers are indicated in the Table 6 .

[50] Figure 13 indicates the averaged HER computed for the period 17-24 January. Simulations show that HER decreases very sharply above $200 \mathrm{~m}$ to reach low values at $1 \mathrm{~km}$. Above $1 \mathrm{~km}$, the aged biomass burning aerosol considerably increases the average heating rate in the layer between 1.5 and $4 \mathrm{~km}$ altitude. Simulations indicate that HER due to aerosols varies between 0.66 and $2.20 \mathrm{~K} \mathrm{day}^{-1}$ (mean value $1.50 \mathrm{~K} \mathrm{day}^{-1}$ ) in the first aerosol layer (Table 6) and between 1.29 and $3.27 \mathrm{~K} \mathrm{day}^{-1}$ in the BBL (mean of $1.90 \mathrm{~K} \mathrm{day}^{-1}$ ). HER in the BBL reaches up to $3.27 \mathrm{~K}$ day $^{-1}$ for 17 January. For comparison, Keil and Haywood [2003] observed that biomass burning aerosols increase HER by $1.77 \mathrm{~K} \mathrm{day}^{-1}$ in the BBL $(1.8-3.7 \mathrm{~km})$ during SAFARI 2000. Keil and Haywood [2003] also indicate that HER can reach up to $2.05 \mathrm{~K} \mathrm{day}^{-1}$ for a SSA of 0.86 . These values are found to be very consistent with the one obtained from our GAME simulations (1.91 $\mathrm{K} \mathrm{day}^{-1}$ ) performed at Djougou.

\section{Conclusion}

[51] The purpose of this work was to investigate the clear sky direct radiative forcing of aerosols over the groundbased station of Djougou, located in Northern Benin, during the AMMA dry season experiment (January-February 2006). The results presented in this work are based on ground-based measurements for estimating aerosol optical (scattering and absorption coefficients) and physical (number size distribution) properties. Additionally, we used the UK BAe 146 aircraft, PHOTON Sun photometer, micro pulse lidar and MODIS observations for estimating, respectively, vertical profiles of thermodynamic parameters, spectral variation of the aerosol optical depth (AOD), aerosol extinction vertical profiles and surface albedo. All this information has been used as input in the discrete ordinate radiative transfer model GAME, for computing the clear sky direct radiative forcing of aerosols.

[52] During this period, Sun photometer measurements indicate a mean AOD of $0.78 \pm 0.24$ (at $440 \mathrm{~nm}$ ), indicating a significant aerosol loading over Djougou. The average aerosol absorption and scattering coefficients at the surface are equal to 15.2 and $145.3 \mathrm{Mm}^{-1}$ (at $520 \mathrm{~nm}$ ) respectively, leading to a mean (and standard deviation) single scattering albedo of $0.91 \pm 0.05$ over the period studied. At the same time, the aerosol number size distribution is shown to be composed by three modes, with a fine (characterized by a mean geometric diameter of $0.096 \mu \mathrm{m}$ ), an accumulation (mode diameter of $0.8 \mu \mathrm{m}$ ) and a coarse (mode diameter of $2 \mu \mathrm{m})$ mode.

[53] In addition to ground-based observations, vertical profiles of aerosol extinction coefficient have been investi- 
gated through a micropulse lidar (MPL). Our results indicate a complex vertical structure, characterized by the presence of two distinct aerosol layers, with a first one located between the surface and $1 \mathrm{~km}$ and a second elevated layer $(1.5-4.0 \mathrm{~km})$. Furthermore, lidar profiles indicate also that the majority of the solar extinction over Djougou is due to the second aerosol layer, composed in majority by smoke particles, which contribute $70 \%$ of the total AOD.

[54] Our radiative transfer simulations performed between 17 and 24 January indicate that aerosols at Djougou lead to a significant diurnal average (and standard deviation) reduction of $61.5 \pm 12.9 \mathrm{~W} / \mathrm{m}^{2}$ in the surface solar radiation, an increase of $43.1 \pm 10.5 \mathrm{~W} / \mathrm{m}^{2}$ in the atmospheric solar absorption, and an increase of $18.4 \pm$ $3.1 \mathrm{~W} / \mathrm{m}^{2}$ in the reflected solar radiation at the top of atmosphere. In order to extend our simulations, we have used the mean BOA, TOA, and ATM forcing efficiency (obtained during 17-24 January), with AOD measured during all the dry season. Averaged over the whole dry season, our results indicated mean values of $-45.0,-13.6$, and $+31.4 \mathrm{~W} / \mathrm{m}^{2}$ for BOA, TOA, and ATM forcings, respectively, which is consistent with calculations performed for smoke aerosols in the Amazonian region.

[55] Changes in heating rates due to the presence of aerosols have been also investigated and discussed. The results we obtained indicate that the heating rates within the BHL and BBL are considerably enhanced, with a mean value of 1.50 and $1.90 \mathrm{~K} \mathrm{day}^{-1}$, respectively. Regarding such radiative forcings and changes in heating rates, future work is now clearly required for investigating the possible impact on the surface-atmosphere system during the dry season over the West African region.

[56] Acknowledgments. On the basis of a French initiative, AMMA was built by an international scientific group and is currently funded by a large number of agencies, especially from France, UK, US, and Africa. It has been the beneficiary of a major financial contribution from the European Community's Sixth Framework Research Programme. AMMA has been endorsed by IGBP (IGAC, ILEAPS) and WCRP (GEWEX, CLIVAR). Detailed information on scientific coordination and funding is available on the AMMA International web site (http://www.amma-international.org). We would like also to thank the PHOTON staff for the data collection, calibration, and processing and especially the PHOTON PIs D. Tanre (LOA) and L. Blarel (LOA). FAAM is jointly funded by the Met Office and the Natural Environment Research Council.

\section{References}

Abel, S. J., E. J. Highwood, J. M. Haywood, and M. A. Stringer (2005), The direct radiative effect of biomass burning aerosols over southern Africa, Atmos. Chem. Phys., 5, 1999-2018.

Ackerman, A. S., O. B. Toon, D. E. Stevens, A. J. Heymsfield, V. Ramanathan, and E. J. Welton (2000), Reduction of tropical cloudiness by soot, Science, 288, 1042-1047, doi:10.1126/science.288.5468.1042.

Alfaro, S. C., et al. (2003), Chemical and optical characterization of aerosols measured in spring 2002 at the ACE-Asia supersite, Zhenbeitai, China, J. Geophys. Res., 108(D23), 8641, doi:10.1029/2002JD003214.

Anderson, T. L., and J. A. Ogren (1998), Determining aerosol radiative properties using the TSI 3563 integrating nephelometer, Aerosol Sci. Technol., 29, 57-69, doi:10.1080/02786829808965551.

Anderson, T. L., S. J. Masonis, D. S. Covert, N. C. Ahlquist, S. G. Howell, A. D. Clarke, and C. S. McNaughton (2003), Variability of aerosol optical properties derived from in situ aircraft measurements during ACE-Asia, J. Geophys. Res., 108(D23), 8647, doi:10.1029/ 2002JD003247.

Bellouin, N., O. Boucher, M. Vesperini, and D. Tanre (2004), Estimating the aerosol direct radiative perturbation: Impact of the ocean surface representation and aerosol non-sphericity, Q. J. R. Meteorol. Soc., 130, 2217-2232, doi:10.1256/qj.03.136.
Carrico, C. M., et al. (2000), Aerosol optical properties at Sagres, Portugal, during ACE 2, Tellus Ser. B, 52, 694-716, doi:10.1034/j.16000889.2000.00049.x.

Chand, D., P. Guyon, P. Artaxo, O. Schmid, G. P. Frank, L. V. Rizzo, O. L. Mayol-Bracero, L. V. Gatti, and M. O. Andrea (2006), Optical and physical properties of aerosols in the boundary layer and free troposphere over the Amazon Basin during the biomass burning season, Atmos. Chem. Phys., 6, 2911-2925.

Chung, C. E., V. Ramanathan, D. Kim, and I. Podgorny (2005), Global anthropogenic aerosol direct forcing derived from satellite and groundbased observations, J. Geophys. Res., 110, D24207, doi:10.1029/ 2005JD006356.

Dubovik, O., and M. D. King (2000), A flexible inversion algorithm for retrieval of aerosol optical properties from Sun and sky radiance measurements, J. Geophys. Res., 105(D16), 20,673-20,696, doi:10.1029/2000JD900282.

Dubovik, O., A. Smirnov, B. N. Holben, M. D. King, Y. J. Kaufman, T. F. Eck, and I. Slutsker (2000), Accuracy assessments of aerosol optical properties retrieved from AERONET Sun and sky-radiance measurements, J. Geophys. Res., 105(D8), 9791-9806, doi:10.1029/ 2000JD900040.

Dubovik, O., B. N. Holben, T. F. Eck, A. Smirnov, Y. J. Kaufman, M. D. King, D. Tanre, and I. Slutsker (2002), Variability of absorption and optical properties of key aerosol types observed in worldwide locations, J. Atmos. Sci., 59, 590-608, doi:10.1175/1520-0469 (2002)059<0590: VOAAOP $>2.0 . C O ; 2$.

Dubuisson, P., J. C. Buriez, and Y. Fouquart (1996), High spectral resolution solar radiative transfer in absorbing and scattering media: Application to the satellite simulation, J. Quant. Spectrosc. Radiat. Transfer, 55, 103-126, doi:10.1016/0022-4073(95)00134-4.

Dubuisson, P., D. Dessailly, M. Vesperini, and R. Frouin (2004), Water vapor retrieval over ocean using near-infrared radiometry, J. Geophys. Res., 109, D19106, doi:10.1029/2004JD004516.

Eck, T. F., et al. (1998), Measurements of irradiance attenuation and estimation of aerosol single scattering albedo for biomass burning aerosol in Amazonia, J. Geophys. Res., 103(D24), 31,865-31,878, doi:10.1029/ 98JD00399.

Ek, T. F., et al. (2001), Characterization of the optical properties of biomass burning aerosols in Zambia during the 1997 ZIBBEE field campaign, J. Geophys. Res., 106(D4), 3425-3448, doi:10.1029/2000JD900555.

Eck, T. F., et al. (2003), Variability of biomass burning aerosol optical characteristics in southern Africa during the SAFARI 2000 dry season campaign and a comparison of single scattering albedo estimates from radiometric measurements, J. Geophys. Res., 108(D13), 8477, doi:10.1029/2002JD002321.

Feingold, G., H. Jiang, and J. Y. Harrington (2005), On smoke suppression of clouds in Amazonia, Geophys. Res. Lett., 32, L02804, doi:10.1029/ 2004GL021369.

Formenti, P., et al. (2001), Saharan dust in Brazil and Suriname during the Large-Scale Biosphere Atmosphere Experiment in Amazonia (LBA) Cooperative LBA Regional Experiment (CLAIRE) in March 1998, J. Geophys. Res., 106(D14), 14,919-14,934, doi:10.1029/2000JD900827.

Formenti, P., et al. (2002), STAAARTE-MED 1998 summer airborne measurements over the Aegean Sea 2. Aerosol scattering and absorption, and radiative calculations, J. Geophys. Res., 107(D21), 4551, doi:10.1029/ 2001JD001536.

Ganguly, D., and A. Jayaraman (2006), Physical and optical properties of aerosols over an urban location in western Indian: Implications for shortwave radiative forcing, J. Geophys. Res., 111, D24207, doi:10.1029/ 2006JD007393.

Guyon, P., et al. (2005), Airborne measurements of trace gases and aerosol particles emissions from biomass burning in Amazonia, Atmos. Chem. Phys. Disc., 5, 2791-2831.

Hansen, J., M. Sato, and R. Ruedy (1997), Radiative forcing and climate response, J. Geophys. Res., 102, 6831-6864, doi:10.1029/96JD03436.

Haywood, J. M., and V. Ramaswamy (1998), Global sensitivity studies of the direct radiative forcing due to anthropogenic sulfate and black carbon aerosols, J. Geophys. Res., 103(D6), 6043-6058, doi:10.1029/ 97JD03426.

Haywood, J. M., S. R. Osborne, P. N. Francis, A. Keil, P. Formenti, M. O. Andrea, and P. H. Kaye (2003), The mean physical and optical properties of regional haze dominated by biomass burning aerosol measured from the C-130 aircraft during SAFARI 2000, J. Geophys. Res., 108(D13), 8473, doi:10.1029/2002JD002226.

Heintzenberg, J., et al. (2006), Intercomparisons and aerosol claibrations of 12 commercial integrating nephelometers of three manufacturers, J. Atmos. Oceanic Technol., 23, 902, doi:10.1175/JTECH1892.1.

Hess, M., P. Koepke, and I. Schult (1998), Optical properties of aerosols and clouds: The software package, Bull. Am. Meteorol. Soc., 79, 831844, doi:10.1175/1520-0477(1998)079<0831:OPOAAC $>2.0 . \mathrm{CO} ; 2$. 
Holben, B. N., et al. (1998), AERONET-A federated instrument network and data archive for aerosol characterization, Remote Sens. Environ., 66, 1-16, doi:10.1016/S0034-4257(98)00031-5.

Intergovernmental Panel on Climate Change (2007), Changes in atmospheric constituents and in radiative forcing, in Climate Change 2007: The Physical Science Basis, Contribution of Working Group I to the Fourth Assessment Report of the Intergovernmental Panel on Climate Change, edited by S. Solomon et al., pp. 129-234, Cambridge Univ. Press, Cambridge, U.K.

Jiang, H., and G. Feingold (2006), Effect of aerosol on warm convective clouds: Aerosol-cloud-surface flux feedbacks in a new coupled large eddy model, J. Geophys. Res., 111, D01202, doi:10.1029/2005JD006138.

Keil, A., and J. M. Haywood (2003), Solar radiative forcing by biomass burning aerosol particles during SAFARI 2000: A case study based on measured aerosol and cloud properties, J. Geophys. Res., 108(D13), 8467, doi:10.1029/2002JD002315.

Koren, I., Y. J. Kaufman, L. A. Remer, and J. V. Martins (2004), Measurement of the effect of Amazon smoke on inhibition of cloud formation, Science, 303, 1342-1345, doi:10.1126/science.1089424.

Leahy, L. V., T. L. Anderson, T. F. Eck, and R. W. Bergstrom (2007), A synthesis of single scattering albedo of biomass burning aerosol over southern Africa during SAFARI 2000, Geophys. Res. Lett., 34, L12814, doi:10.1029/2007GL029697.

Léon, J.-F., P. Chazette, J. Pelon, F. Dulac, and H. Randriamarisoa (2002), Aerosol direct radiative forcing impact over the INDOEX area based on active and passive remote sensing, J. Geophys. Res., 107(D19), 8006 , doi:10.1029/2000JD000116.

Liousse, C., H. Cachier, and S. G. Jennings (1993), Optical and thermal measurements of black carbon aerosol content in different environments Variation of the specific attenuation cross section, sigma (s), Atmos. Environ. Part A, 27, 1203-1211, doi:10.1016/0960-1686(93)90246-U.

Magi, B. I., and P. V. Hobbs (2003), Effects of humidity on aerosols in southern Africa during the biomass burning season, J. Geophys. Res., 108(D13), 8495, doi:10.1029/2002JD002144

Mallet, M., J. C. Roger, S. Despiau, O. Dubovik, and J. P. Putaud (2003), Microphysical and optical properties of aerosol particles in urban zone during ESCOMPTE, Atmos. Res., 69(1-2), 73-97, doi:10.1016/ j.atmosres.2003.07.001

Mallet, M., R. V. Dingenen, J. C. Roger, S. Despiau, and H. Cachier (2005), In situ airborne measurements of aerosol optical properties during photochemical pollution events, J. Geophys. Res., 110, D03205, doi:10.1029/2004JD005139

Mallet, M., V. Pont, C. Liousse, J. C. Roger, and P. Dubuisson (2006) Simulation of aerosol radiative properties with the ORISAM-RAD model during a pollution event (ESCOMPTE 2001), Atmos. Environ., 40 7696-7705, doi:10.1016/j.atmosenv.2006.08.031.

Mayol-Bracero, O. L., R. Gabreil, M. O. Andreae, T. W. Kirchstetter, T. Novakov, and D. G. Streets (2002), Carbonaceous aerosols ove the Indian Ocean during INDOEX: Chemical characterization, optical properties and probable sources, J. Geophys. Res., 107(D19), 8030, doi:10.1029/2000JD000039.

Osborne, S. R., B. Johnson, and J. Haywood (2008), Physical and optical properties of mineral dust aerosol during the Dust and Biomass Experiment (DABEX), J. Geophys. Res., doi:10.1029/2007JD009551, in press

Öström, E., and K. J. Noone (2000), Vertical profiles of aerosol scattering and absorption measured in situ during the North Atlantic Characterization Experiment (ACE-2), Tellus Ser. B, 52, 526-545, doi:10.1034 j.1600-0889.2000.00050.x.

Pelon, J., M. Mallet, A. Mariscal, S. Crewell, S. Victori, D. Tanre, and J. Haywood (2008), Characterization of biomass burning aerosol from microlidar and colocated observations at Djougou (Benin) during AMMA/SOP-0, J. Geophys. Res., doi:10.1029/2008JD009976, in press.

Petzold, A., C. Kopp, and R. Niessner (1997), The dependence of the specific attenuation cross section on black carbon mass fraction and particle size, Atmos. Environ., 31, 661-672, doi:10.1016/S13522310(96)00245-2.

Procopio, A. S., et al. (2004), Multiyear analysis of Amazonian biomass burning smoke radiative forcing of climate, Geophys. Res. Lett., 31 L03108 doi:10.1029/2003GL018646.

Putaud, J. P., et al. (2000), Chemical mass closure and assessment of the origin of the submicron aerosol in the marine boundary layer and the free troposphere at Tenerife during ACE-2, Tellus Ser. B, 52, 141-168, doi:10.1034/j.1600-0889.2000.00056.x.
Quinn, P., D. J. Coffman, T. S. Bates, and D. S. Covert (2000), Chemical and optical properties of ACE-2 aerosol, Tellus Ser. B, 52, 239-257.

Ramanathan, V., et al. (2001), The Indian Experiment: An integrated assessment of the climate forcing and effects of the great Indo-Asian haze, J. Geophys. Res., 106, 28,371-28,398, doi:10.1029/2001JD900133.

Redelsperger, J.-L., C. D. Thomcroft, A. Diedhiou, T. Lebel, D. J. Parker, and J. Polcher (2006), African Monsoon Multidisciplinary Analysis: An international research project and filed campaign, Bull. Am. Meteorol. Soc., 87, 1739-1746.

Reid, J. S., R. Koppmann, T. F. Eck, and D. P. Eleuterio (2005), A review of biomass burning emissions part II: Intensive physical properties of biomass burning particles, Atmos. Chem. Phys., 5, 799-825.

Rissler, J., A. Vestin, E. Swietlicki, G. Fisch, J. Zhou, P. Artaxo, and M. O. Andreae (2006), Size distribution and hygroscopic properties of aerosol particles from dry-season biomass burning in Amazonia, Atmos. Chem. Phys., 6, 471-491.

Roger, J. C., M. Mallet, P. Dubuisson, H. Cachier, E. Vermote, O. Dubovik, and S. Despiau (2006), A synergetic approach for estimating the local direct aerosol forcing: Application to an urban zone during the Expérience sur Site pour Contraindre les Modèles de Pollution et de Transport d'Emission (ESCOMPTE) experiment, J. Geophys. Res., 111, D13208, doi:10.1029/2005JD006361.

Ross, J. L., P. V. Hobbs, and B. N. Holben (1998), Radiative characteristics of regional hazes dominated by smoke from biomass burning in Brazil: Closure tests and direct radiative forcing, J. Geophys. Res., 31,92531,941, doi:10.1029/97JD03677.

Schafer, J. S., B. N. Holben, T. F. Eck, M. A. Yamasoe, and P. Artaxo (2002), Atmsopheric effects on insolation in the Brazilian Amazon: Observed modification of solar radiation by clouds and smoke and derived single scattering albedo of fire aerosols, J. Geophys. Res., 107(D20), 8074, doi:10.1029/2001JD000428

Schafer, J. S., T. F. Eck, B. N. Holben, P. Artaxo, M. A. Yamasoe, and A. S. Procopio (2002), Observed reductions of the total irradiance by biomassburning aerosols in the Brazilian Amazon and Zambian Savanna, Geophys. Res. Lett., 29(17), 1823, doi:10.1029/2001GL014309.

Schmid, O., et al. (2006), Spectral light absorption by ambient aerosols influenced by biomass burning in the Amazon Basin. Part I: Comparison and field calibration of absorption measurement techniques, Atmos. Chem. Phys., 6, 3443-3462.

Stamnes, K., S. Tsay, W. Wiscombe, and K. Jayaweera (1988), Numerically stable algorithm for discrete-ordinate-method radiative transfer in multiple scattering and emitting layered media, Appl. Opt., 27, 2502-2509.

Thompson, A. M., et al. (2003), Southern Hemisphere Additional Ozonesondes (SHADOZ) 1998-2000 tropical ozone climatology 1. Comparison with Total Ozone Mapping Spectrometer (TOMS) and ground-based measurements, J. Geophys. Res., 108(D2), 8238, doi:10.1029/ 2001JD000967.

Twomey, S. (1977), The influence of pollution on the short wave albedo of clouds, J. Atmos. Sci., 34, 1149-1152, doi:10.1175/15200469(1977)034<1149:TIOPOT>2.0.CO;2.

Weingartner, E., H. Saathoff, M. Schnaiter, N. Streit, B. Bitnar, and U. Baltensperger (2003), Absorption of light by soot particles: Determination of the absorption coefficient by means of aethalometers, J. Aerosol Sci., 34, 1445-1463, doi:10.1016/S0021-8502(03)00359-8.

P. Dubuisson, LOCL/MREN, ELICO, 32 Avenue Foch, Wimereux F-62930, France. (phillippe.dubuisson@univ-littoral.fr)

P. Goloub, Laboratoire of Optique Atmospherique, USTL, CNRS, Bat P5 Cite Scientifique, Lille F-59655, France. (phillippe.goloub@univ-lillel.fr)

L. Gomes, CNRM, Météo-France, 42 Avenue Gustave Coriolis, Toulouse F-31057, France. (laurent.gomes@meteo.fr)

J. Haywood and S. Osborne, Met Office, FitzRoy Road, Exeter, EX1 3PB, UK

C. Liousse, M. Mallet, A. Mariscal, V. Pont, and V. Thouret, Laboratoire d'Aérologie, UPS, CNRS, UMR5560, 14 Avenue Edouard Belin, Toulouse F-31400, France. (malm@aero.obs-mip.fr)

J. Pelon, Service d' Aéronomie, University of Jussieu, 4 Place Jussieu, CEDEX 05 Paris F-75252, France.

J. C. Roger, LAMP, OPGC, 24 Avenue des Landais, Clermont-Ferrand F63177, France. (j-claude.roger@opgc.univ-bpclermont.fr) 